\title{
PROCESO CREATIVO EN LA OBRA DE ERNESTO SABATO
}

\author{
POR \\ SILVIA SAUTER \\ Kansas State University
}

\section{EL TUNEL: DIFERENCIACION INICIAL}

Ernesto Sábato es uno de los escritores contemporáneos que más ha discutido acerca de la polaridad "diurna y nocturna" de su propio proceso creativo; lo ha hecho en ensayos y entrevistas, lo ejemplifica y dramatiza en su ficción y, recientemente como pintor, lo expresa en la imagen visual. Aunque la crítica en general reconoce su dualidad creadora, lúcida a un extremo y arcana o visionaria al otro, no se ha analizado el funcionamiento de dicho proceso creativo en su primera novela El túnel (1948) ${ }^{1}$. En esta obra se prefigura la perspectiva multifacética que continúa en las novelas subsiguientes, Sobre héroes y tumbas (1961) y Abaddón el exterminador (1974) ${ }^{2}$, y se encuentra el germen de las preocupaciones, obsesiones y temas de la obra sabatiana. Se inicia también la prolongada y penetrante indagación de un proceso creativo extremadamente complejo y conflictivo con el fin de desentrañar su funcionamiento, pues constituye la fuerza motriz de la ficción sabatiana y de la propia vida de Sábato, como él mismo lo ha expresado innumerables veces ${ }^{3}$.

\footnotetext{
1 A los catorce años ya había escrito su primer relato de ficción, según Angela B. Dellepiane, Sábato: Un análisis de su narrativa (Buenos Aires: Nova, 1970), 22. Su primera novela, La fuente muda, inédita salvo por el capítulo "La muerte en el barro", publicada en Sur 157 (noviembre 1947) y reproducida en La robotizacion del hombre y otras paginas de ficción y reflexión (Buenos Aires: Centro Editor de América Latina, 1981).

${ }^{2}$ Ernesto Sábato, El túnel (Buenos Aires: Sudamericana, 1977); Sobre héroes y tumbas (Barcelona: Seix Barral, 1978); Abaddon el exterminador (Barcelona: Seix Barral, 1982). En lo sucesivo abreviaré estos títulos a: $E T, S H T$ y $A E E$ respectivamente y daré las referencias en el texto.

${ }^{3}$ Se doctoró en Física cum laude en 1937. Recomendado por Bernardo Houssay, Premio Nobel de Física, fue becado en 1938 para trabajar en el laboratorio Curie en París. Pese al prestigio y seguridad económica de esta carrera, la dejo para dedicarse al arte, su primera vocación. En El escritor y sus fantasmas (Barcelona: Seix Barral, 1979) escribe sobre su crisis personal: "... volví por segunda vez a París. Pero cuando comencé mis tareas, con Irène Joliot, comprendí de pronto que todo eso noera más que una complicadísima
} 
Aunque el conocimiento de la biografia sobre el autor no es indispensable para analizar su obra, Ernesto Sábato es uno de los casos en que vida y obra se entrecruzan e influyen mutuamente ${ }^{4}$.

Sin embargo, mi propósito no es discutir la personalidad del escritor Ernesto Sábato, sino analizar la estructura psicológica del proceso creativo, que empieza a revelarse a partir de $E T$; examinar aspectos de la personalidad creadora del protagonista de ET Pablo Castel, sus desdoblamientos, sueños, pesadillas y fantasías que dramatizan la diferenciación de algunas de las funciones psíquicas que conforman el proceso creativo; distinguir los factores de la personalidad de Castel todavía indiferenciados que inciden en el proceso creativo y que son por lo general proyectados en otros personajes, así como señalar ciertos acontecimientos externos que inducen al artista al acto creativo.y afectan su producción artística. En la figura de Castel y su doble visión creadora se encuentra el germen de la multiplicidad de encarnaciones y reencarnaciones que conformarán las diferentes facetas del proceso creativo en las novelas $S H T$ y $A E E$ que completan la trilogía empezada con $E T^{5}$. Según Graciela Maturo, las constantes preocupaciones de Sábato ya se encuentran en $E T$, "punto de partida de una largay auténtica trayectoria" donde se "asoman los temas fundamentales

evasion, y en el fondo una cobarde salida a mis auténticos problemas interiores. Empecé a vincularme con los surrealistas, particularmente con Oscar Domínguez, y de ese modo creo que se inició la etapa final (y más auténtica) de mi existencia. Supe entonces que mi paso por la ciencia había terminado para siempre" (11).

${ }^{4}$ Abundan los análisis de la personalidad, biografía, problemática personal y la producción literaria de Sábato. Se destacan: Joaquín Neyra, Ernesto Sábato: el hombre y la obra (Buenos Aires: Ministerio de Cultura y Educación, 1973); Angela Dellepiane, Sábato: Un andlisis de su narrativa y Ernesto Sabato: el hombre y su obra (New York: Las Americas, 1968); Carlos Catania, Sábato, entre la idea y la sangre (San Jose: Ed. Costa Rica, 1973) y Genio y figura de Ernesto Sábato (Editorial Universitaria de Buenos Aires, 1987); Mariana Petrea, Ernesto Sabato: la naday la metafísica de la esperanza (Madrid: Porrúa, 1986); Editorial, s.n. "Ernesto Sábato: novelador del abismo e indagador tenaz y esperanzado de la condición humana", Anthropos 55-56 (1985): 2-32, números dedicados a la vida, obra y temas de Sábato con una extensa bibliografia. Véanse también Nicasio Urbina, "Bibliografía Crítica completa de Ernesto Sábato, con un índice temático", Revista de crttica literaria lationoamericana 27 (1988): 177-222.

'En general, la crítica sabatiana concuerda en que las tres novelas de Sábato constituyen una trilogía por su coherencia y unidad. A. M. Vázquez Bigi lo afirma en "Abbaddón: Ascendencia cervantina para una temática apocalíptica", Texto Crítico 15 (oct.-dic. 1979): 48-65 y en su introducción a Epica dadora de eternidad: Sábato en la critica americana y europea (Buenos Aires: Sudamericana/Planeta, 1985), 29-43, discute artículos en esta edición que coinciden en dicho punto, como los de: Cesare Segre "Cuando llega el exterminador: (Término de la famosa trilogía de Sábato)", 179-182; y Anita Padial, "Historia y poesía de la épica sabatiana", 235-240. Ver también: Elisa Calabrese, "De El Túnel hasta Abbadon el Exterminador: Trayectoria de una trilogia", Sur 348 (1981): 89 93; y Gustavo Siebenmann, "Ernesto Sábato y su postulado de una novela metafísica", Revista Iberoamericana 118-119 (1982): 289-302. 
... que se desarrollan y amplifican en toda su obra posterior" $(604)^{6}$. David Foster señala que desde $E T$, "one story is told several times. It is the story of the despair of sensitive individuals confronted by an irrational and degrading existence" $(73)^{7}$, en busca de una salida por diferentes vías; pero que son a menudo conducidos hacia el conocimiento profundo a través del arte.

Castel como narrador, protagonista y supuesto escritor de la novela, atormentado por sus vanos esfuerzos de trascendencia y alienado entre millares de seres deshumanizados en la gran urbe moderna persigue, más que busca, una unión íntima con alguien que lo entienda y que capte lo "esencial" en su pintura (14). Debido a una escena clave en su cuadro "Maternidad", entra en contacto con Maria. Según Castel, ella era: "la única persona que evidentemente había comprendido [su] pintura" (35) y reitera al final "Sólo existió un ser que entendía mi pintura" (141). María es también su posible medio de salvación pero, al no conseguir la total posesión de ella, la mata. En el cuadro se destaca "la gran mujer en primer plano, la mujer que miraba jugar al niño", mientras,

...arriba, a la izquierda, a través de una ventanita ... una escena pequeña y remota: una playa solitaria y una mujer que miraba el mar. Era una mujer que miraba como esperando algo, quizá algún llamado apagado y distante. La escena sugería ... una soledad ansiosa y absoluta (14).

La gran figura en primer plano anticipa el destino de Castel que quedará psicológicamente sometido a la figura simbólica matriarcal. La intuición que le hizo producir la escena vital por la cual logra comunicarse con Maria, procede de la misma fuente inconsciente que lo impulsa al conocimiento íntimo. Este se logra mediante la paulatina integración de polaridades psíquicas en conflicto, pero el exagerado racionalismo del personaje transforma el posible proceso de integración en un proceso de desintegración ${ }^{8}$.

Entregado doblemente al arte, falla como pintor al no poder reproducir la realidad psíquica subyacente en la escena del cuadro. Falla también en su intento de comunión total con María, lo cual genera su escritura: confesión retrospectiva de su fragmentación y de su crimen. Al matar a María, Castel rompe el puente entre el incesante racionalizar que lo ciega y aísla y la

"En "Sábato: la búsqueda dela salvación", Cuadernos Hispanoamericanos 391-393(1983): 602-620, G. Maturo examina la ficción sabatiana como el recorrido del héroe que logra "la integración de la propia individualidad" a través de la creación novelística.

${ }^{7}$ David W.Foster, "Ernesto Sabato and the Anatomy of a National Unconscious", Currents in the Contemporary Argentine Novel (University of Missouri Press, 1975), 70-97.

${ }^{8} \mathrm{G}$. Maturo, quien también le atribuye al arte un lugar primordial en la vida y temática de Sábato, considera en "El túnel como acceso a la vida nueva" en Epica (op. cit.), 73-87 que Castel logra la salida de su proceso de iniciacion y que por matar a María "ha podido transformarse de niño en hombre ... que comprende el error, y por lo tanto es capaz del acto reparador de la palabra" (83). 
posibilidad de conexión con la otredad, autoconocimiento o trascendencia mediante la integración del principio femenino (ánima), que él proyecta primero en la escena del cuadroy después en la figura de María con quien la escena queda identificada ${ }^{9}$. Con la destrucción de su cuadro clave y el asesinato de María, Castel cierra la avenida que podría haberlo sacado de su encierro cerebral. Tampoco en la escritura de la novela encuentra la salida a su unilateralidad suprarracionalista. Sin embargo, aunque Castel queda fragmentado en el universo literario por haber apuñalado a María, la lectura del sacrificio sangriento puede convertirse en un rito de iniciación para el lector partícipe, de acuerdo a sus necesidades psicológicas, factor afectivo que influye en el nivel receptivo de la lectura ${ }^{10}$.

Castel encarna la personalidad creadora en pugna consigo mismo y con su sociedad. También el carácter compulsivo y la persistencia del artista para mejor expresar su doble vertiente creadora: la externa y diáfana, resultante del aspecto espiritual consciente y dinámico que aspira a las alturas y produce la obra concreta, y la interna, arcana, visionaria, manifestación de lo inconsciente, lo anímico y difuso, matriz receptiva que a la vez nutre y genera la creación ${ }^{11}$. El personaje ilustra también las provocaciones que estimulan el proceso

\footnotetext{
${ }^{8}$ La psicologia analítica (Carl Jung, Erich Newmann, Ira Progoff, James Hillman, entre otros) denomina anima a la contraparte sexual psíquica masculina yanimus a la femenina. Por lo general se la proyecta en individuos del sexo opuesto. Según Jung, son "Personificaciones de una naturaleza femenina en el inconsciente del hombre y de una naturaleza masculina en el inconsciente de la mujer. Esta doble sexualidad psíquica corresponde al hecho biológico de que el predominio de genes masculinos (femeninos) decide en la determinación del sexo .... El menor número de genes del sexo contrario parece formar un carácter contrasexual que, sin embargo, a causa de su supeditación permanece habitualmente inconsciente" Recuerdos, sueños, pensamientos, 3a. ed., Trad. Ma. Rosa Borrás (Barcelona: Seix Barral, 1981), 409.

${ }^{10}$ En las últimas décadas ha habido una proliferación térica sobre la recepción de la lectura con énfasis en el lector para darle sentido e interpretar el texto. David Bleich en Subjective Criticism (Baltimore: John Hopkins University Press, 1978) y Norman Holland en 5 Readers Reading (New Haven: Yale University Press, 1975), presuponniendo que la motivación predominante en el individuo es el autoconocimiento, han explorado la lectura como un proceso que satisface las necesidades psicologicas del lector. Propongo que, como parte del autoconocimiento, la lectura activa de algunas obras puede servir como alternativa para llenar la vacuidad de ritos de pasaje significativos en la sociedad moderna occidental.

${ }^{11}$ Un nivel que pertenece al espíritu (animus) es el arquetipo del sentido=logos, la producción creativa; mientras que al alma=psique (ánima) le pertenece el arquetipo de la vida y de los orígenes; es la fuente de creación. Véase Carl G. Jung, The Collected Works, ed. Herbert Read et al. Trad.R.F.C.Hull, Bollingen Series XX (Princeton:Princeton University Press, 1978), vol. 9, par. 58-80 (en adelante $C W$, vol. y número de párrafo). Naturalmente, dada la tradición occidental, se comprende mejor y se valora mucho más el primer nivel, ignorando o rechazándose el segundo por su carácter contradictorio e insondable. Para Sábato, ambos son fuente de su novelística y parte de la vida concreta.
} 
creativo visionario, aunque como ente literario no discrimina los contenidos inconscientes que a menudo lo dominan ${ }^{12}$.

Castel enfrenta situaciones que provocan la actividad creadora y marcan el descubrimiento progresivo del ámbito inconsciente a través del arte. Lidia Balkenende señala: "El artista es un inmenso poliedro en donde existen luces que se apagan mientras otras se prenden. Y en ese poliedro de Sábato, Castel vive y se retuerce en su angustia existencial" $(18)^{13}$. La reiterativa imagen del poliedro ilustra el funcionamiento de un claro-oscuro mental desorientado que Castel mismo nota cuando dice: "Mi cabeza es un laberinto oscuro. A veces hay como relámpagos queiluminan algunos corredores. Nunca termino de saber por qué hago ciertas cosas" (39). Pese a su inteligencia, sensibilidad e intuición creadora, como individuo urbano moderno, cínico y suprarracional, Castel es incapaz de detener la maquinaria intelectual; quiere entenderlo y explicarlo todo. En su incesante diálogo consigo mismo se pregunta, “¿acaso yo no razonaba?" y responde: "Por el contrario, mi cerebro estaba constantemente razonando como una máquina de calcular" (39). Justo en el momento en que está a punto de desplazar la razón por la intuición, automáticamente vuelve a la racionalización, la duda y el temor que lo dejan más desorientado. Aunque ha "encontrado a Maria" por casualidad, atribuye el encuentro a la causalidad de su "capacidad lógica" (39), pero inmediatamente ante el miedo ilógico de perderla se da cuenta de su desorientación y le confiesa a María,

... razono siempre. Pero imagine usted un capitán que en cada instante fija matemáticamente su posición y sigue su ruta hacia el objetivo con un rigor implacable. Peroquenosabe por quéva hacia ese objetivo, ¿entiende? $(39$, énfasis del autor).

\footnotetext{
${ }^{12} \mathrm{El}$ proceso creativo visionario es un complejo autónomo arquetípico. El arquetipo, principio inconsciente creativo de naturaleza bipolar, organizador y precursor de ideas, subyace bajo las discrepancias e inexplicables paradojas de la condición humana, es el principio psiquico integrante que transforma lo instintivo en espiritual. Lo arquetípico es al espíritu lo que el instinto es al cuerpo: "In archetypal conceptions and instinctual perceptions, spirit and matter confront one another on the psychic plane. Matter and spirit both appear in the phsychic realm as distinctive qualities of conscious contents. The ultimate nature of both is trascendental, that is, irrepresentable, since the psyche and its contents are the only reality which is given to us without a medium", escribe Jung ( $C W$ 8, par. 420). Por su funcionamiento dinámico, autónomo e imperioso, Jung los denominó reguladores u organizadores inconscientes de ideas o formas primarias complejas del pensamiento en Aion, ed. Herbert Reed et al. Trad. R.F.C. Hull (Princeton: Princeton University Press, 1979), vol. 9 II, par. 278. Como dominantes de la psique, impelen a decir cosas o realizar acciones opuestas a la intención consciente. Subraya Jung: "it is especially important to picture the archetypes of the unconscious not as a rushing phantasmagoria of fugitive images but as constant, autonomous factors" (Aion) vol. 9 II, par. 40.

${ }^{13}$ Lidia Balkenende, Aproximaciones a la novelistica de Sábato (Buenos Aires: Agencia Periodística C. I. D., 1983).
} 
No dice rigor impecable sino implacable, análogo a su desborde cerebral. Equipara el pensamiento preciso a la violencia cuando escribe: "Sólo horas más tarde mis pensamientos empezarían a alcanzar la precisión y la violencia de otras veces" (112). En otro momento reitera el oximoron: "Mi cerebro funcionaba ya con la lúcida ferocidad de los mejores días"(124), ilustrando aś la agresividad de la unilateralidad racionalista, uno de los síntomas del individuo occidental contemporáneo desarraigado por la descentralización de valores jerárquicos o hieráticos que lo guiaban y limitaban tradicionalmente. Lo que éste gana en libertad lo pierde en orientación, guía moral y esperanza de trascendencia o supervivencia, con la consecuente ansiedad frente al vacío que la razón y el materialismo por sí solos no pueden compensar. Según José Ortega, el ensimismamiento de Castel lo aísla en su fortaleza: "Castel (arcaísmo que significa castillo)" (127), o bien espacio psíquico donde "se refugia una fuerza espiritual vigilante, construida por falsos sistemas autodefensivos" $(127)^{14}$.

Aunque no reconozca su desnivel emocional, relacionado directamente con su suprarracionalidad, Castel tiene un desarrollado sentido crítico e intelectual capaz de distinguir su propia escición entre la razón, compasión y buenas intenciones. Al mismo tiempo puede criticar sus propias reacciones explosivas, sus "bajas acciones" (80-83) y defectos semejantes a los que nota en otros. También es capaz de reconocer a su "otro yo ... en una especie de inmunda cueva" (81) y es capaz del mirar objetivo necesario para diferenciar sus propios complejos ${ }^{15}$. Esto contrasta radicalmente con su irracional concepción de María, no soporta que ella sea superficial como Hunter y Mimí (100), que goce de su sexualidad (69) ni que puedan haber "cosas tan oscuras y despreciables" (111) en la vida de ella como las hay en la de él, porque nada de esto encaja en la virginal proyección que inconscientemente Castel le ha impuesto a María (106, 107 \& passim). Poco antes de matarla, en un examen retrospectivo mientras espia la casa de Hunter, cavila sobre sus encuentros con ella en un ir y venir entre "un río oscuro y tumultuoso ... y casi mar inmovil y perpetuo" que los "arrastraba como en un sueño a tiempos de infancia" y él

... la veía correr desenfrenadamente en su caballo, con los cabellos al viento y los ojos alucinados, y yo me vef́a en mi pueblo del sur, en mi pieza de enfermo, con la cara pegada al vidrio de la ventana, mirando la nieve con ojos también alucinados. Y era como si los dos hubiéramos estado viviendo en pasadizos o túneles paralelos, sin saber que rbamos el uno al lado del otro, como almas

\footnotetext{
${ }^{14}$ José Ortega, "Las tres obsesiones de Sábato", Cuadernos Hispanoamericanos, 391-393, (enero-marzo 1983): 125-51.

${ }^{15}$ En este caso su sombra (shadow) asi llamada por ser el aspecto desconocido más bochornoso o elevado de la psique propia, lo difícil de aceptar en uno mismo, pero cuyo reconocimiento es el paso sin el cual no hay posibilidad de conocimiento profundo. La diferenciación y asimilación de este complejo implica el reconocimiento de los defectos propios y, a menudo, virtudes aparentemente inalcanzables.
} 
semejantes en tiempos semejantes, para encontrarnos al fin de esos pasadizos, delante de una escena pintada por mí, como clave destinada a ella sola, como un secreto anuncio de que ya estaba yo allí y que los pasadizos se habían por fin unido y que la hora del encuentro habia llegado (134-135).

Naturalmente, no conocía a María entonces, pero su visión corresponde a una necesidad interna muy antigua de unión íntima con su propio principio femenino, que en la infancia es proyectado en la madre y corresponde al aspecto receptivo creador. En el individuo emocionalmente maduro equivale al ánima, se proyecta en una compañera o parejaen iguales condiciones; pero, al proyectarlo en Marí, Castel le adjudica a ésta el papel de Madre Virgen, comprensiva y pura a la vez ${ }^{16}$. Cuando la conducta de María, casada con otro y amante de él, además de otras relaciones que tuvo y posiblemente tiene, traiciona esta imposición, su proyección adolescente la transforma en la Madre Terrible, devoradora pero imprescindible para él; en detrimento del desarrollo de su ego ya bastante débil, lo cual es evidente por su inseguridad emocional, timidez, dependencia, arranques pueriles y otras reacciones sintomáticas reveladas en su conducta y en su pensar: "Lo que más me indignaba, ante el hipotético engaño" escribe Castel "era el haberme entregado a ella completamente indefenso, como una criatura" (70). Aunque él tiene treinta y ocho años y ella "no más de veintiséis", Castel admite sentirse "como si fuera un niño" al lado de María (66). En otra ocasión recuerda que, en respuesta a las caricias de María, "Como con mi madre, puse la cabeza sobre su regazo y así quedamos un tiempo quieto, sin transcurso, hecho de infancia y de muerte" (107). Es posesivo con el tiempo de María, como un niño ${ }^{17}$. Al escribirle que se va a suicidar se regocija con la idea de entristecerla (87-8), como el adolescente emocional que es, dependiente y nostálgico de la seguridad embriónica. Sin embargo, este anhelo no consiste simplemente en el deseo sexual infantil reprimido hacia la propia madre o complejo edípico, a menudo atribuido a Castel ${ }^{18}$. Su búsqueda de lo absoluto, su

\footnotetext{
${ }^{16}$ Así lo ve J. Ortega entre otros: “... la mujer solitaria y expectante del lienzo que juega con el niño ... mujer que podría considerarse como madre devoradora-protectora. Esta función materna la asimila Castel a María: 'ella lo acaricia como madre' ... 'a veces se siente como un niño asustado' ... Maternidad fntimamente relacionada con el problema de la identidad de Castel, pues, por un lado, se siente atraído por este símbolo de lo más permanente e intrahistórico, y, por otro, esta atracción obtaculiza su independencia síquica y de aquí su miedo a tomar decisiones" (130).

${ }^{17}$ Se evidencia su egocentrismo por el uso del pronombre en primera persona al principio de casi cada capítulo. Lo repite setenta y una veces en las seis primeras páginas hasta que empieza a hablar de su pintura.

${ }^{18}$ Para la escuela freudiana, segín Jean LaPlanche and Bertrand Pontalis, Diccionario de Psicoanalisis. trad. F. Cervántez Gimeno (Barcelona: Labor, 1983), el complejo de Edipo consiste en el "conjunto organizado de deseos amorosos y hostiles que el niño experimenta respecto a sus padres. En su forma llamada positiva, el complejo se presenta como en la historia de Edipo Rey deseo de muerte del rival que es el personaje del mismo sexo y deseo sexual hacia el personaje del sexo opuesto" (61). Para Jung, en cambio, el
} 
necesidad de comunicación completa y de trascendencia apuntan a una mayor hondura y complejidad que la mera satisfacción de los sentidos en la proyección materna. Maríarepresenta para él la imago de la Gran Madre, el gran receptáculo creador mítico, la madre tierra, primera entraña, morada última, desconocido principio y fin; en suma, lo inconsciente o fuente de creación. Pero al no distinguir la proyección simbólica, su ego en desarrollo queda subyugado a la fascinación y se disuelve hundiéndose en el vértigo abismal, lo cual implica el incesto psíquico o atadura ourobórica, es decir, la conexión psicológica del adolescente con la imagen dominante materna. Esta conexión se rompe simbólicamente en sueños, ritos de iniciación o de pasaje, mediante el incesto simbólico de penetración en la ballena, cueva o laberinto, seguido por la salida de la profundidad desconocida, después de darle muerte al monstruo o a su equivalente. Con ello se logra "una diferenciación del ego, separación de los Padres Universales y desmembramiento del dragón primordial ${ }^{19}$. Dicho rito de transformación promovería la toma de conciencia de Castel, paso a la madurez previo a la proyección del ánima, libre de temores adolescentes. De otro modo, el débil ego sometido al multifacético arquetipo de la Gran Madre pierde control de su vida anímica. Paradójicamente, al matar a María, impulsado por la necesidad de integración con el misterio que ella representa, Castel destruye la llave de su propia fuente creadora. Sin embargo, para el lector receptivo, el ritual percibido como símbolo tiene la capacidad de transformar la energía psíquica. Además ilustra los peligros del excesivo y constante racionalizar del ente moderno urbano que encarna el personaje literario. Pese a ser Castel el artista intuitivo que reconoce en María un alma afín, su desmedida racionalidad cierra las puertas a la compenetración íntima que anhela. Sin comprender la imposibilidad de una unión total con otro ser, se da cuenta de que el túnel era sólo suyo, que había visto a María "en uno de esos trozos transparentes del muro de piedra ... y había creído ingenuamente que venía por otro túnel paralelo ... cuando en realidad pertenecía al ancho mundo" (135). Ella funciona separada de él y no puede ser, comoél quisiera, la figura de la escena que lo espera "muda y ansiosa" (136), reflejo de su inconsciente que él no discrimina, ni puede asimilar, por lo cual al darse cuenta de la autonomía de María, receptáculo de su proyección, queda en total soledad.

complejo de Edipo y el femenino que denominó complejo de Electra (este último no aceptado por Freud), se consideran simbolicamente como aspectos del arquetipo de origen. No se interpretan literalmente ni ocupan un papel tan preponderante en la personalidad como el que Freud le atribuye. Puesto que en mitos, leyendas, sueños y literatura el fenómeno es simbolico, al no tratarse de seres de carne y hueso, sino de personificaciones de aspectos inconscientes, no se los puede reducir a sintomas personales. ${ }^{19}$ Erich Neumann, The Origins and History of Consciousness, 1954, trad. R. F. C. Hull (Princeton: Princeton University Press, 1973). "...differentiation of the ego, separation of the World Parents, and dismemberment of the primordial dragon" [traduccion mia en el texto] o la serpiente ouroborus, que sería la manera de "set man free as a son and expose him to the light, and only then is he born as a personality with a stable ego" (106). 
Se ha dicho a menudo que Castel es egoista y arrogante; pero, al no ser de carne y hueso, vive en la mente del lector en la medida en que representa un aspecto psicológico existencial de la personalidad. No vive en la identificación literal. Dramatiza la crisis del individuo moderno, alienado de su sociedad, en busca de comunicación y armonía interna, pero impotente en el proceso de integración por su incapacidad de reconocer y dejar actuar al principio femenino en sí mismo. La ceguera de Castel, opuesta a la del marido de Maria, Allende, físicamente ciego pero psicológicamente vidente, ejemplifica al hombre unilateral, escindido de lo inconsciente ${ }^{20}$. Analizador intemperado, de extraordinaria inteligencia, Castel es capaz de reconocer la irracionalidad y monstruosidad de acontecimientos cotidianos, dándose cuenta de su propia división, pero es incapaz de ahondar en sus propios sentimientos, emociones, acciones, motivaciones y reacciones involuntarias. El contraste entre su desarrollado intelecto y su inmadurez emocional se ilustra en la destrucción de sus cuadros que anticipa la aniquilación de María. Lo hace con zaña, vengándose a la vez de una crítica miope y repetitiva:

había algo que quería destruir sin dejar siquiera rastros ... no vacilé: a través de mis lágrimas vi confusamente cómo cafa en pedazos aquella playa, aquella remota mujer ansiosa, aquella espera. ¡Ya nunca más recibiría respuesta aquella espera insensata! ¡Ahora sabía más que nunca que esa espera era completamente inútil! (131-32).

El estado de su obra en añicos refleja el de su alma (psique) y sus acciones sellan el destino inconscientemente impuesto: su desesperanza, infructuosa búsqueda e incesante autocuestionamiento, especialmente sobre el significado del grito, “Insensato!” que le "aulló el ciego" Allende al oír que mató a María ${ }^{21}$.

\footnotetext{
${ }^{20}$ Según J. Ortega "El problema fundamental de Castel es que su 'yo' no logra conciliarse consigo mismo" con la parte afectiva de su naturaleza. "Juan Pablo, consciente o inconscientemente, trata de encontrar su totalidad, su individuacion, segín Jung, integrando la parte inconsciente de la sique, que es anterior a la conciencia, y con la que funciona simultáneamente. El activo mundo simbólico (inconsciente) de Juan Pablo es parte del proceso (exitoso o fallido) para integrar su personalidad con un todo, liberándose del dominio de los arquetipos familiares (madre/María) y sociales. Su fracaso se debe a no haber podido, o sabido, establecer una relación auténtica consigo mismo y con la realidad" (128). Aunque Castel es intelectualmente maduro, emocionalmente no lo es, lo cual imposibilita todo intento de una "relación auténtica". Antes de esto tendría que diferenciar y asimilar varios contenidos inconscientes.

${ }^{21}$ Para Natalia Bogdánova “... Sábato ... por boca de Allende ... dicta sentencia a su personaje ... Castel 'es un insensato', porque al matar enterro con sus propias manos la esperanza de salvarse de la soledad y es el castigo más duro que pudo inventar el autor para su protagonista" (67). "El mundo de Ernesto Sábato", América latina 6/88, Academia de Ciencias de la URSS: Instituto de América Latina (Moscu: Ed. Progreso Moscri, 1988): 61.71.
} 
Ya se ha señalado que el ciego ve más claro y más lejos que $\operatorname{Castel}^{22}$ y que, por lo tanto, conoce la realidad interior que María representa. Castel en cambio, enceguecido por los celos, producto de su inmadurez, apuñala a María como antes a sus cuadros, sintiendo por ello "como si el demonio ya estuviera para siempre en [su] espíritu" (139). Al someterse al inconsciente (fuente creativa y/ o infierno), la oscuridad se agiganta apoderándose de su espíritu incapaz ya de discriminación alguna. En su huída del sitio del crimen, Castel ve que "los relámpagos" que están fuera ya no iluminan su interior como lo hacían anteriormente y observa que le "mostraron, por última vez, un paisaje que [les] había sido común" (139).

Según Riccardo Campa ${ }^{23}$, "Castel prefiere no saber a no poseer" (266). Mientras permanece en la ignorancia de la personalidad femenina de María, la preserva como ideal: "La grandeza y la belleza deben ser oscuras y sagradas. De otro modo decaen" (264). Por lo tanto, "Matando a María ... la salva de la degradación que sufriría si se hiciese comprensible, si se replegase en la infinita estupidez de adoptar la convención del 'bien' para darle alegría a él, indigno como todos- de la grandeza" (266). Pero, muerto el objeto de su proyección, Castel renuncia al conocimiento propio; el ideal queda en suspenso y el factor femenino inconsciente propio que lo instigó a pintar la ventanita y a lograr ráfagas de comunión con María, se transforma en la fuerza destructiva que lo empuja a destruir lo mismo que persigue. Castel suicida su naturaleza receptivo-generadora, la matriz de su creación. Devorado por el vientre ourobórico, queda atrapado en su propio túnel obscuro sin sentido y sin salida, como parece haber quedado desde el punto de vista de Bruno, quien piensa al verlo en las páginas de $A E E$ : "Ese hombre ... está absoluta y definitivamente solo", parecía tener "sesenta años, caminaba encorvado ... su ropa estaba deshilachada ... como distraído: era evidente que no iba a ninguna parte, que nadie lo esperaba, que todo le era igual" (167-68). Hundido en la locura razonable, Castel parece seguir analizando sin comprender. Al final de ET se dice a sí mismo que necesitaba "razonar la última palabra del ciego, la palabra insensato. Un cansancio muy grande o quizá oscuro instinto" piensa Castel, se "lo impide reiteradamente". Se propone analizar "también los motivos que pudo haber tenido Allende para suicidarse" (141). A diferencia de Allende, la ceguera de Castel consiste en la ignorancia (inconciencia) de su propia naturaleza, donde queda atrapado. Según Campa "En su calidad de artista, Castel es testimonio

${ }^{22}$ Luis Wainerman, en Sabatoy el misterio de los ciegos (Buenos Aires: Losada, 1971), nota que el apellido del ciego "Allende ... alude al horizonte [sic] del mirar, la otra cara de las cosas, el reverso que los videntes no ven porque tienen sólo un recorte, un escorzo de los objetos. Los ciegos, con su 'omnisciencia sagrada', lo ven todo, $y$, por otra parte, como notará Castel, miran en general “ (enfasis en el original, 36).

${ }^{23}$ Riccardo Campa, "Ernesto Sábato" en Homenaje a Ernesto Sábato: variaciones interpretativas en torno a su obra, Helmy F Giacoman ed. (Madrid: Anaya, 1973), 260-72. 
no protagonista de la existencia. Por tanto, debe continuar viviendo pero con tristeza, tendiendo a la locura. Su misión es la de aislar el misterio y transmitirlo integro" (267). Lologra. Aunque el personaje queda auto-escindido en el mundo novelístico, en su confesión persiste el misterio de su verdadera motivación para sacrificar a María, rito que mantiene la vitalidad y riqueza semántica del símbolo plurivalente que tiene la capacidad de transformar la energía psíquica del lector receptivo.

En la novela, Castel termina escribiendo su confesión encerrado en un calabozo entre "los muros de este infierno ... cada día más herméticos" y pintando con la sospecha de "que los médicos se ríen" de él, como cree que lo hacían de "la escena de la ventana" (140-141). Indudablemente Castel acierta, en parte al menos, pues la postura cientificista no aceptaría el nexo comunicativo atemporal e inconsciente a través del arte, función que Castel le atribuye a la escena de la ventanita de su cuadro, análoga al postulado sabatiano sobre la novela total. Escribe Castel: "estábamos solos nosotros dos, como lo intuí desde el momento en que ella miró la escena de la ventana ... ¿cómo podía no tutearme si nos conocíamos desde siempre, desde mil años atrás?" (p. 60). El referente es la imagen que facilitó la comunicación en un espacio psíquico a nivel profundo $\mathrm{y}$ atemporal.

\section{EL TÚNEL, ANTICIPO A LA PERSPECTIVA MULTIFACÉTICA EN LA NARRATIVA SABATIANA ${ }^{24}$}

Todo lo anterior anticipa ramificaciones y meandros posteriores que dramatizan la dinámica del proceso creativo en diferentes momentos, épocas y niveles. Algunos de ellos ilustran los aspectos conscientes que Sábato llama la parte diurna del proceso creativo, los mismos que sin ser necesariamente conceptualizaciones univocas, son comprensibles. Las imágenesincomprensibles, en cambio, proceden del ámbito inconsciente, semejante al espacio onírico o mítico y se prestan a interpretaciones simbólicas. En la ficción sabatiana, según Jerzy Kühn, ET correspondería al sueño inicial de una serie en la cual los siguientes sueños aclaran y amplían el primero:

Después de haber soñado "sabemos" más, pero nuestro conocimiento escamotea todas las formulas. Porque el sueño, tal como la novela, la poesía o la pintura opera con símbolos que no encuentran lugar en el lenguaje objetivo (p. 775 $)^{25}$.

\footnotetext{
${ }^{24}$ Renato Prada Oropeza en "El túnel: Sentido y proyección" Texto Critico 15 (oct.-dic. 1979): 7-22, analiza: "1. La configuración discursiva y 2. La relación (valor) del texto en el contexto del sistema literario del narrador Sábato". En la segunda parte ubica $E T$ en el contexto más amplio de la narrativa sabatiana mostrando sagazmente una amplia diversidad de relaciones entre las tres novelas.

${ }^{25}$ Jerzy Kühn, "Las fronteras del compromiso", Cuadernos Hispanoamericanos 391-393 (enero-marzo 1983): 769-779.
} 
Efectivamente, el psicodrama del artista, todavía indiferenciado en $E T$, se va discerniendo en las dos novelas siguientes. Varios aspectos de la compleja personalidad de Castel son personificados o animados por diversas figuras en un proceso de diferenciación, necesario y previo a la reconciliación de oposiciones que produce armonía. La paranoia de Castel se bifurca y alterna, centrándose en el proceso creativo visionario más extensamente, pero sin perder su intensidad. La necesidad de expresar su oscura trayectoria, que convierte a Castel en escritor, seguirá con los siguientes exploradores del submundo mitopoético sabatiano. En SHT, Bruno es escritor y lúcido confidente del protagonista Martín, quien también aspira a escribir, mientras Fernando, otra figura principal, lega a la humanidad su "Informe sobre ciegos", ambiguo testimonio de un descenso dionisíaco al submundo bonaerense. Su recorrido es análogo al que seguirá el escritor, personaje y narrador Sabato (sin acento) y "diferente" a Sábato, el autor en $A E E$. Aquí reaparece Brunode $S H T$, más lúcidoen su función narrativa pero impotente como ëscritor. Lo acompañan algunos jóvenes poetas frustrados y torturados tanto física (Marcelo) como psicológicamente (Nacho). En las dos últimas novelas, el loco Barragán encarna el aspecto desequilibrado pero profético de Castel; bebe más que éste para escapar de sus visiones, pero se hunde más en ellas. En $A E E$, el personaje Sabato comparte las visiones con Barragán. El laberinto inexplorable dentro de la cabeza de Castel $(27,39,42)$ se externaliza y expande en el laberíntico submundo de cloacas y tinieblas con breves ráfagas de luz (zona psíquica transpersonal) en el que se hunden, exploran y del cual salen Fernando para morir en $S H T$ y Sabato para transformarse en rata-murciélago en $A E E$. El tema de la ceguera, apenas esbozado en $E T$, con el pensamiento de Castel "como el de un gusano ciego y torpe dentro de un automóvil a gran velocidad" (27) y el efecto duradero de la última palabra de Allende en el protagonista, se amplía y profundiza hasta el delirio en las siguientes novelas. Los sentimientos ambivalentes de Castel por la mujer imposible que personifica María se bifurcarán en otras proyecciones femeninas e.g.: el odio y desprecio de Bruno por su madre en SHT y su amor imposible por la misteriosa y polifacética Alejandra, quien se desdoblará en $A E E$ en su propio espectro en sueños y apariciones, y también en otras figuras femeninas más discernibles, como Agustina, Beba y Silvia por un lado, y por otro, en personificaciones teriomórficas (de forma humana y animal) como Nora y Soledad. También la percepción de Castel de "María como una figura silenciosa e intocable ..." (135), es análoga a la que tiene Bruno en SHT sobre Alejandra y a la del personaje Sabato en $A E E$ acerca de Soledad, Nora y el fantasma de Alejandra. El peligro femenino, alma, instinto creativo, ternura pero también vértigo, implícito en la amenaza indirecta de María con su temor de hacerle daño a Castel $(43,106)$, se repite con variaciones. La sensibilidad adolescente y angustiada de Castel, así como el anhelo de absolutos y esperanza de trascendencia serán igualmente reiterados ${ }^{26}$. En diversa proporción, algunos

${ }^{26}$ D. Foster distingue entre Castel y Martín, siendo el último "the boy who suffers ... adolescent whose less than su perior intelligence means that he is dazed by life most of the 
personajes (Fernando, Alejandra, Sabato, Nacho, Agustina) heredan el sentido crítico, la inteligencia, la sensibilidad y el cinismo de Castel. Fernando, Sabato, Silvia, Quique y Jorge Ledesma practican crítica y teoría literaria iniciados por Castel y Hunter (96-99 y passim) y la recepción frívola de la lectura de Mimí en ET se distribuye entre personajes menores (92-96). El intento del artista de recrear el poder misterioso de la escena de la ventanita, nexo ambiguo que sólo María, ejemplo de receptividad, percibe, será reproducido en la impotencia frente a la escritura de varios personajes, especialmente en las trabas que el personaje Sabato encuentra a cada paso para escribir la misma novela $A E E$ de la que es protagonista. La naturaleza soberbia, más alla de la moral, pero instintivamente creativa de Castel toma forma en figuras aún más sombrías como Fernando $(S H T)^{27}$, Jorge Ledesma y un ente animado inescrutable reconocido sólo por la inicial $\mathrm{R}$. ( $A E E$ ). Haciendo eco a su creador Sábato, Fernando, Nacho y naturalmente el personaje Sabato heredan de Castel su desprecio a la frivolidad, arrogancia y trivialidad de grupos elitistas; a la imitación de modas aparentemente originales que exhibe mucha de la literatura y crítica literaria modernas; al mercantilismo y vacuidad de los sistemas de comunicación en general; al individualismo y colectivismointeresados; a grupos asociados que exhiben una falsa superioridad con jergas especializadas destinadas a impresionar. Todo ello anticipa parcialmente la mordacidad y el abierto disgusto desplegado en la trilogía hacia los cánones sociales y académicos prevalentes. Personajes representativos como Mimí Allende y Hunter, que encarnan algunas de las fobias de Castel, serán seguidos por otros aún más estereotipados. Las imágenes extrañas como la rata viva que sirve de alimento humano, la metamorfosis de Castel en su pesadilla y otras imágenes oníricas propias del proceso creativo visionario se expanden y multiplican en las siguientes novelas reiterando el horror, falta de solidaridad y crueldad humanas.

\section{ACTOS RITUALES Y SUEÑOS SIMBOLICOS A PARTIR DE EL TUNEL}

Una característica ritual inconsciente, previa a un acto creativo o a un momento vital, empieza con Castel confesándole a María su instintiva e incomprensible necesidad de ella, mientras traza "dibujos geométricos en la tierra" (38); en la misma conversación tan reveladora de su interioridad vuelve "a dibujar con la ramita" (39). El ritual se repite en $S H T$, "A veces con un palito,

time ... Bruno, the frustrated novelist who is the confidant for Martin's outpourings of confusion, fear and despair, underlines the novel's focus. Rather than on the abnormal overintelligent individual of The Tunnel, the novel centers instead on his more normal counterpart, Martín" (74). En Castel se reúnen los varios aspectos de la psique en pugna, mientras enSHT la separación dela sobreinteligencia(Bruno) y la sensibilidad adolescente (Martín), resultan en un Martín menos complicado.

${ }^{27}$ Fernando en su infancia tortura pájaros en SHT y en el recuerdo de Bruno, "Fernando cortando las patas traseras de un sapo" en $A E E$ (460). 
con una ramita seca, etc.” (cit. en Dellepiane, p. 317), y Sabato y Nacholo siguen realizando inconscientemente en $A E E$.

$\mathrm{El}$ análisis total de los elementos seminales en $E T$ y su expansión en $S H T$ y $A E E$ sería interminable y excede el alcance de este trabajo. Sin embargo, los sueños en $E T$ prefiguran algunos de los acontecimientos en las novelas siguientes e inciden directamente en la progresiva inmersión del artista en el ámbito inconsciente, surtidor del material que inicia el proceso creativo visionario. La estructura de los sueños, como la del drama, es arquetípica. Los actores representan la actividad inconsciente del soñador, quien no pierde su identificación con la imagen que lo representa ni con sus propias emociones. Los objetos son también rasgos propios del que sueña, como "la vieja casa solitaria" que Castel visita en su primer sueño. Según Castel, "era una casa en cierto modo conocida e infinitamente ansiada ... desde la infancia", pero en este espacio que representa algo suyo, se "encontraba perdido en la oscuridad o tenía la impresión de enemigos escondidos". Puesto que él ignora los contenidos inconscientes propios, siente el natural temor a lo desconocido, pero también "sentía que en esa casa renacian ... los antiguos amores de la adolescencia, con los mismos temblores" (58). Al despertar concluye que "la casa del sueño era María", espacio onírico que recuerda y lo acompaña desde la infancia, proyección maternal transferida ahora a María con los mismos sentimientos ambivalentes "esa sensación de suave locura, de temor y de alegría" (58), análoga a sus reacciones incomprensibles.

El segundo sueño prefigura algunos acontecimientos futuros. Castel relata la metamorfosis ocurrida en una pesadilla ${ }^{28}$. Después de ver al dueño de la casa donde había sido invitado, piensa:

Intuí que había caído en una trampa y quise huir. Hice un enorme esfuerzo, pero era tarde: mi cuerpo ya no me obedecía. Me resigné a presenciar lo que iba a pasar, como si fuera un acontecimiento ajeno a mi persona. El hombre aquel comenz6 a transformarme en pájaro, en un pájaro de tamaño humano (85-86).

Al contrario del sueño anterior, en los sueños impersonales la reacción anímica es transpersonal y puede ser muy intensa. El sujeto se siente ajeno a la imagen que lo representa, indicio de una relación con el ámbito colectivo. Los sueños se interpretan como el drama por su estructura análoga. Mientras sea posible la identificación con los sucesos y personajes, el drama es individual. Pero la pesadilla de Castel, con mayor afinidad al teatro del absurdo por su carácter alienante, no puede analizarse de la misma manera que un drama de amor. Además, los procesos psíquicos en el nivel instintivo se manifiestan en

${ }^{28}$ Ortega analiza los tres sueños de Castel desde una perspectiva junguiana modificada al considerar a María como figura de la gran madre arquetípica y ánima a la vez. 
sueños mediante simbolismoteriomórfico(imaginería de forma animal ${ }^{29}$. Cuanto menos domesticados los animales, más profunda es la raíz de donde brotan las imágenes y más se acercan al ámbito arquetípico elemental, base del folklore espontáneo de los pueblos, como los mitos, fábulas, leyendas, cuentos de hadas y otras manifestaciones espontáneas análogas. El sueño de Castel prosigue de un modo alarmante:

Empeź́ por los pies: vi cómo se convertían poco a poco en unas patas de gallo - algo así. Después siguió la transformación de todo el cuerpo ... Mi única esperanza estaba ahora en los amigos ... cuando por fin llegaron, sucedi6 algo que me horroriz6: no notaron mi transformación. Me trataron como siempre, lo que probaba que me veían como siempre (86).

Nadie más que Castel se da cuenta de su metamorfosis en pájaro-gallo, animal más o menos doméstico, pero de dimensión anormal en el sueño:

Pensando que el mago los ilusionaba de modo que me vieran como una persona
normal, decidí referir lo que me habia hecho ... comencé a contar todo a gritos
.. la frase que quería pronunciar salio convertida en un áspero chillido de
pájaro, un chillido desesperado y extraño, quizá por lo que encerraba de
humano; y, lo que era infinitamente peor, mis amigos no oyeron ese chillido,
como no habian visto mi cuerpo de gran pajjaro; por el contrario, parecían oír mi
voz habitual diciendo cosas habituales .... El dueño de casa me miró entonces
con un sarcástico brillo en sus ojos ... solo advertido por mi. Entonces comprendí
que nadie, nunca, sabría que yo había sido transformado en pajaro. Estaba
perdido para siempre y el secreto iŕa conmigo a la tumba (86-87).

La transformación de Castel, ignorada por las otras figuras en el sueño, que en realidad representan aspectos todavía no diferenciados del mismo sujeto, lo sitúa en un estado privilegiado (aunque aterrorizante). Desde el punto de vista personal, el mago representaría otro aspecto de la sombra de Castel que lo hace obrar de manera ilógica como un pájaro incomprendido ${ }^{30}$. El ave al mismo tiempo sugiere una jaula, prefigurando su futuroencierro. Se podria interpretar esta imagen como una tentativa del inconsciente para comunicarle a Castel su ineficacia en escuchar a María (106-107) y a su propio inconsciente. También sugiere su intento de quitarle la libertad a María, quien necesita estar libre para volar $^{31}$. De igual modo lo femenino/creativo en Castel debe exteriorizarse libremente, sin el continuo cuestionamiento al que éste somete toda manifestación

\footnotetext{
${ }^{29}$ Según Jung "Theriomorphic symbolism is always an indication of a psychic process occurring on an animal level, i.e., in the instinctual sphere ${ }^{n}(\mathrm{CW}$, vol. 14, par. 178). O sea el nivel más elemental y común a la humanidad, llamado inconsciente colectivo por ser transpersonal.

${ }^{30}$ Véase nota 15.

${ }^{31}$ Karla Henne sugirí esta idea en un ensayo inédito.
} 
espontánea, cuestionamiento análogo al que somete a María. Los amigos que no lo oyen corresponden a su falta de comunicación con el mundo exterior; e.g., la escena del correo en que la empleada lo oye pero no lo escucha (115-120). Igualmente, la fiesta y los amigos compensan la falta de éstos en su vida, sólo se le conoce uno, Mapelli (132). En lo colectivo, sirve de advertencia al individuo moderno desequilibrado por su unilateralidad. Además, siguiendo a Jung, la imagen visionaria (siempre simbólica), por la carga de energía psíquica de la que está dotada, tiene la capacidad de compensar el desequilibrio psíquico sociocultural causado por la sobrevaloración que la sociedad le otorga a alguno de los aspectos que la componen.

\section{PATRONES AFECTIVOS QUE INDUCEN A LA GESTACION ARTISTICA A PARTIR DE EL TUNEL}

Un proceso creativo tan complejo y ajeno a la experiencia del individuo promedio, dramatizado tan vívidamente en la ficción sabatiana, ofrece la ventaja de un examen directo del acto creativo más allá de hipótesis cognoscitivas, psicológicas o críticas. Por ejemplo, se ilustran algunos indicios que provocan el estado receptivo del creador visionario, imposibles de ser registrados por ningún estudioso del fenómeno que no haya experimentado su impetuosidad. Empezando en ET surgen sueños, transformaciones e imágenes alienantes que parecen fuera de lugar; algunas de éstas activan el sistema inconsciente que saca al artista de su encasillamiento racional. Castel menciona la noticia de una instancia inexplicable lógicamente, pero que constata la degradación de la conciencia humana contra su propia especie:

Que el mundo es horrible, es una verdad que no necesita demostración. Bastaría un hecho para probarlo, en todo caso: en un campo de concentración un ex pianista se quejó de hambre y entonces lo obligaron a comerse una rata, pero viva.

No es de eso, sin embargo, de lo que quiero hablar ahora; ya diré más adelante, si hay ocasión, algo más sobre este asunto de la rata (10, énfasis del autor).

Tras este preámbulo anuncia su intención de escribir, pero, no obstante el distanciamiento de su discurso, la imagen del horror promueve la modalidad creativa no producida por una motivación racional: "Podrán preguntarse qué me mueve a escribir la historia de mi crimen (no sé si ya dije que voy a relatar mi crimen) y, sobre todo, a buscar un editor" (10). Vuelve más tarde al incidente de la rata, no para explicarlo sino para subrayar el sin sentido del mundo: "tiene algo que ver con la humanidad en general" (42), le confiesa a María, pero señala al mismo tiempo el efecto catalizador que lo empujó a pintar la escena de la ventanita tan fuera de lugar en su cuadro "Maternidad". Recuerda "como hablando para sí mismo", 
... que días antes de pintarla habra leido que en un campo de concentración alguien pidió de comer y lo obligaron a comerse una rata viva. A veces creo que nada tiene sentido. En un planeta minúsculo que corre hacia la nada desde millones de años, nacemos en medio de dolores, crecemos, luchamos, nos enfermamos, sufrimos, hacemos sufrir, gritamos, morimos, mueren y otros están naciendo para volver a empezar la comedia inutil (42).

Su anterior obra, sin ser superficial, era ejecutada intelectualmente, pero dice Castel, "esa escena no, sentía que debía pintarla así, sin saber bien por qué. Y sigo sin saber. En realidad, no tiene nada que ver con el resto del cuadro y hasta creo que uno de esos idiotas me lo hizo notar. Estoy caminando a tientas" (41). En la penumbra de lo inconsciente, que más tarde articula en la escritura, añade, "ahora me daba cuenta hasta qué punto había pintado la escena de la ventana como un sonámbulo" (42).

Por segunda vez la misma alusión a la rata, que evoca una extraordinaria atmósfera de pesadilla no sólo por la imagen misma sino por las connotaciones históricas ya bien conocidas, precede al acto creativo tanto de la escritura de la novela como de la pintura que mejor revela el territorio desconocido para Castel: su temor a la desesperanza y soledad tras el cristal de la ventanita, la cual, sin embargo, deja ver el otro lado, la esperanza de salida o visión de otra realidad. Castel advierte la absorción de María en la escena que casi nadie había notado: "estaba aislada del mundo entero: no vio ni oyó a la gente que pasaba o se detenía frente a mi tela". La imagen simbólica tiende un puente de comunicación a nivel profundo: "Nadie se fijó en esta escena .... Con excepción de una sola persona, nadie pareció comprender que esa escena constituía algo esencial" (14), aunque otra persona la not6́, pero, según Castel, con "aprensión, casi asco" (40). Dicha escena, punto de arranque y núcleo de $E T$, ilustra el proceso creativo visionario ya que la pintó sin un plan, "caminando a tientas" (41), "como un sonámbulo" (42). Al mismo tiempo parece fuera de lugar, como el "Informe" de Fernando en $S H T$, también diferente y aparentemente inconexo en relación con el resto de la novela. Todos estos elementos se van ampliando y expandiendo en $S H T$ y $A E E$ "como si la pequeña escena de la ventana empezara a crecer y a invadir toda la tela y toda mi obra" $(E T, 15)$, prefigura Castel, anticipando las futuras novelas de Sábato.

La fuente creativa que originó la ventanita corresponde al principio pasivo de la psique receptiva, en ansiosa espera como la mujer del cuadro, aspecto que, proyectado en María como medio, no fin, diferenciado y asimilado por el artista, resultaría en la unión simbólica entre polaridades opuestas. Sin embargo, el intento de Castel está destinado al fracaso pues concretiza un fenómeno psíquico. Sólo vuelve al estado receptivo por relampagueantes momentos, movido por la compasión o catarsis ante el horror de la noticia inhumana que lo impulsó a su más verdadera creación. Pero incapaz de permanecer en ese espacio, se pregunta. "¿por qué esa manía de querer encontrar explicación a 
todos los actos de la vida? Cuando comencé este relato estaba firmemente decidido a no dar explicación de ninguna especie. Tenía ganas de contar la historia de mi crimen, y se acabo: al que no le gustara, que no la leyese" (12). Intenta trascender pero, quiéralo o no, se encuentra racionalizando, torturándose con la minucia y el detalle. Cumpl;iendo cobn la promesa de Castel en ET, Sábato retorna a la imagen de la rata en $A E E$, para contrastar la actitud del artista sensible frente a la brutalidad que revelan las noticias con la indiferencia general prevalente. Una señora sin nombre en una reunión social recuerda "que en El túnel se citaba el caso de un pianista que había sido obligado a comer una rata viva”, responde otra: “-Qué asquerosidad”, a lo cual contesta la primera: "-Será asqueroso, pero es lo único bueno de esa novela" (82). En reacción al desfile de horrores que se relatan a continuación, el polo sensible que impulsa la creatividad del personaje, Sábato se desplaza, alejándose del círculo despreocupado e indiferente al dolor humano, observándolos y observando a su propia persona o máscara social que sigue conversando con el grupo.

Catania señala con acierto que "por encima de los apellidos apocalípticos que le han sido asignados" a $A E E$, la novela "constituye en primer término ... un acto de sadomasoquismo, de regeneración y santidad: un intento quizás único en la literatura por observarse como escritor y buscar una justificación, no ya de su obra ... sino ... del mundo mismo donde el escritor implantará su obra como testimonio y voz de aliento" (499) ${ }^{32}$. Tarea que Sábato inicia en ET desde diversidad de perspectivas, en un intento de discernir las facetas del poliedro que es Castel. Sin embargo, las relampagueantes luces en la oscuridad que no orientan a Castel, guiarán a otros personajes, en quienes Castel se desdobla en las siguientes novelas, pese al desasosiego y dudas que los atormenta.

Castel busca su polaridad creadora para equilibrar su unilateralidad racionalizante. Esta búsqueda corresponde al psicodrama del individuo contemporáneo, fragmentado en una sociedad descentralizada sin los valores hieráticos que tradicionalmente orientaban a sus miembros. Aunque el ente literario termina refugiándose en su obsesión racionalista, en su testimonio escrito emerge el ritual arcaico de un sacrificio sangriento todavia vital en la transmisión del símbolo. Este factor afectará el nivel receptivo del lector facilitando su participación en el rito iniciático que Castel lleva a cabo al apuñalar la figura femenina que es simbólicamente una proyección de su propio aspecto receptivo/generador necesario para la producción creadora, paralelo a la fragmentación y deshumanización del ente urbano en la sociedad moderna.

32 Carlos Catania, "El universo de Abaddón el exterminador", Cuadernos Hispanoamericanos 391-393 (enero-marzo 1983): 498-516. 


\section{DESDOBLAMIENTOS Y COMPONENTES PSIQUICOS SUBYACENTES EN LA ESTRUCTURA NARRATIVA DE ABADDON EL EXTERMINADOR}

Abaddón, el exterminador es ante todo un texto autorreflexivo que examina y dramatiza su propio proceso creativo. Esta indagación, iniciada sin éxito por el artista Castel en El túnel, se empieza a discriminar parcialmente entre algunos personajes de Sobre héroes y tumbas y logra una mayor diferenciación en Abaddón el exterminador donde las voces del conjunto, más maduras, se diversifican y alternan. El escritor se exige una mayor compenetración en el mundo novelístico e ingresa al espacio mitopoético de su ficción como protagonista, con su propio nombre modificado (Ernesto Sabato, sin acento) pero con las mismas señas de identidad del individuo-novelista Ernesto Sábato ${ }^{33}$. Sin la máscara que supone adjudicar una experiencia vital tan compleja e incomprensible a uno de sus personajes, Sábato se desdobla como otro personaje en la novela al compartir, por un lado, el peregrinaje del espíritu superlúcido con las criaturas nacidas de su autoanálisis y, por otro, el del alma (psique) al animar parcialmente esta faceta de la personalidad creadora ${ }^{34}$.

En Abaddón, Sabato discrimina algunos aspectos psíquicos de la personalidad creativa y ejemplifica otros componentes inconscientes (transpersonales) que afectan el proceso creativo. Mediante desdoblamientos, proyecciones y visiones que dramatizan la discriminación de múltiples niveles de conciencia, se desarrolla el psicodrama polifónico de voces en pugna entre los móbiles conscientes e inconscientes que mueven y conmueven al creador ${ }^{35}$. Sin embargo, no pretendo analizar la personalidad del individuo Sábato sino, más bien, examinar la función del proceso de diferenciación del protagonista y la fragmentación del aspecto creativo visionario, elementos subyacentes fundamentales que estructuran la narración.

Una tendencia crítica general en la aplicación de los postulados junguianos al análisis de la ficción sabatiana ha consistido en hallar indicios de algunos patrones arquetípicos (o complejos funcionales) siempre presentes en el proceso de individuación (Gran Madre, ego, sombra, anima / animus, persona, entre otros) y compararlos con ciertas figuras constantes en la literatura. Pero en Abaddón,

\footnotetext{
э9 Usaré esta ortografía para diferenciar al personaje Sabato en las páginas de Abaddon, del ciudadano Sábato. La preferencia de este último en la actualidad es firmar su apellido sin la tilde "en su forma originaria y ancestral" (Carta de Ernesto Sábato, noviembre de 1987).

${ }^{34}$ Luis Wainerman elabora sobre la importancia de los nombres en Sábato y el misterio de los ciegos (29-37) y sobre Sábato vs. Sabato (108-110).

${ }^{35}$ José Ortega ya notó que: "La compleja estructura deAbaddón se deriva de la necesidad de captar la riqueza de significados de la realidad humana, es decir, de las contradicciones del individuo y del medio social. Obra, pues, que podría ser categorizada como polifónica en virtud de la elaboración narrativa de ideologías antitéticas, asi como múltiples aspectos de la inagotable y siempre cambiante realidad" (151).
} 
el creador lleva a cabo su propio análisis durante el quehacer literario. En parte el proceso exploratorio sigue los patrones mencionados; pero, hay otra parte que se aparta de lo comprensible y se expande al terreno transpersonal profundizándose hacia raíces remotas e incognoscibles de lo inconsciente.

La escritura lúcida ("diurna" en términos de Sábato) informa, expone ideas, revela el espíritu de la época e ilustra racional e intencionalmente el funcionamiento consciente de la producción artística; mientras que la parte irracional, inverosimil ("nocturna") dramatiza el submundo inconsciente transpersonal, inaccesible al individuo moderno y asequible tan sólo al artista visionario. Este confronta al lector con elementos de la realidad profunda desechados por la unilateralidad e hipocresía racionalistas, pues el representante medio de la civilización occidental moderna, seguro del control de su destino, ha perdido la capacidad primitiva de percibir los indicios subyacentes bajo la urdimbre colectiva. Pese a la evidencia de los horrores diarios, no asume la responsabilidad que le corresponde como miembro de la misma familia, deshumanizándose al rechazarla. El creador visionario trasciende su momento y su circunstancia personal, ofrece una visión única de la condición humana, visión al mismo tiempo tan profunda y remotamente típica (arquetípica) que es irreconocible, pero posee la vitalidad del símbolo genuino plurivalente y misterioso, de inagotable significación, perdurable, atemporal y aespacial. Cuando el creador articula las visiones de su descenso al submundo, realiza un rito primigenio consubstancial con la naturaleza, necesario para el equilibrio psíquico colectivo. El equilibrio se producirá en la medida en que la sensibilidad y la consciencia del grupo, en una época dada, lo permitan ${ }^{36}$.

Los desdoblamientos y componentes subyacentes que estructuran la narración de Abaddón tratan de duplicar la interacción dramática entre diversos aspectos psíquicos del creador: primero, en un proceso de diferenciación, reconocimiento y reintegración a nivel personal y luego, en un proceso de fragmentación simbólico de la polaridad profética a nivel transpersonal. De acuerdo a Jung y otros estudiosos de psicología profunda, la experiencia creativa latente e inherente en el ser humano, manifiesta en sueños, mitos, religión y arte, responde a uno de los principios básicos integrantes de la personalidad humana desde sus inicios ${ }^{37}$.

\footnotetext{
${ }^{36}$ Algunas de estas obras, ignoradas, mal interpretadas o atacadas en su primer momento, son reivindicadas por el tiempo y se revitalizan al expandirse la sensibilidad de una nueva época. Puede toda una generación o un pueblo rechazarla para que otro grupo en otro momento la reivindique. La obra simbólica es universal sin dejar de señalar la circunstancia social particular; oponiéndose al canon colectivo, desafía el momento histórico, trasciende su momento, su circunstancia y a su creador; afecta profundamente y anticipa lo por venir. ${ }^{97}$ En The Death and Rebirth of Psychology. An Integrative Evaluation of Freud, Adler, Jung and Rank and the Impact of their Insights on Modern Man ,Progoff cocluye que en el desarrollo y madurez de sus últimos años, estos cuatro estudiosos de la mente, llegaron casi a las mismas conclusiones, tras perseguir diversas perspectivas que los separa sólo en apariencia. Los cuatro encuentran que el elemento irracional humano apunta más allá
} 


\section{DESDOBLAMIENTOS DIRECTOS E INDIRECTOS DE SABATO}

El personaje Sabato encarna la problemática del creador compulsivo, cuya supersensibilidad está constantemente expuesta al asedio de fuerzas impersonales, espontáneas e incontenibles, de las cuales es y está más consciente que el individuo común y corriente, pero que aún así permanecen indiferenciadas. Dramatiza la impotencia de transmitir cabalmente los impulsos que exigen al visionario explorar esa realidad ignota, así como la incapacidad de aprehender el plan divino/satánico que la misma mente humana crea y recrea en sus cambiantes mitos, pero que es incapaz de comprender en toda su magnitud.

En Abaddón, dice Balkenande, "Sábato se sitúa en personaje y no lo será contando y observando solamente, asumirá su papel descarnado y sufrirá todas las contingencias y la persecución de sus propias criaturas" (29) para compartir con ellas las experiencias conscientes e inconscientes que el proceso de novelar conlleva. El artista visionario compenetrado con las reverberaciones de lo inconsciente transpersonal, ejerce parte de su labor poseído por fuerzas autónomas que, como los personajes de Sábato y a pesar de haber sido engendrados por él, se transforman espontáneamente. Explica Sábato:

El artista se siente frente a un personaje suyo como un espectador ineficaz frente a un ser de carne y hueso: puede ver, puede hasta prever el acto, pero no lo puede evitar .... Lo curioso, lo ontológicamente digno de asombro, es que esa criatura es una prolongación del artista; y todo sucede como si una parte de su ser fuese esquizofrénicamente testigo de la otra parte, de lo que la otra parte hace o se dispone a hacer: y testigo impotente. (Escritor 197, énfasis del autor)

Sabato le confiesa a Silvia su aspiración de no sólo "hacer el examen desde dentro" de la novela, sino de ahondar en ella, poniendo "en juego el propio novelista ... en la misma calidad que los otros [personajes]; que sin embargo salen de su propia alma. Como un sujeto enloquecido que conviviera con sus propios desdoblamientos ... no por espíritu acrobático ... sino para ver si así podemos penetrar más en ese gran misterio" (Abaddón 248-49). Al percatarse de la idea, Sabato transciende de la exposición teórica sobre la creación a la intuición de certidumbre que eludía a Castel y se encuentra simultáneamente en el terreno vivencial, "[c]onducido por sus propios fantasmas, hacia el continente que sólo ellos podían conducirlo. Y así, con los ojos vendados, sentía de pronto que lo llevaban al borde de un abismo, en cuyo fondo estaba la clave que lo atormentaba" (249). El lector retrocede con el personaje al momento inicial de introspección que anticipa su ingreso al espacio novelístico y, al mismo tiempo,

de la psicologia, de los principios de cada uno, de placer-biologico (Freud), de poderinferioridad orgánica (Adler), de individuación-arquetipo unificante trascendental(Jung) y social de superficie (Rank), hacia más allá de la psicología, la lógica y la ciencia, hacia el principio de creación. 
sigue en su lectura la conflictiva travesía del escritor de la novela que está leyendo. El protagonista multifacético-escritor angustiado; pensador, teórico y crítico literario; personaje público; partícipe, a menudo inconsciente; actorexperimentador, soñador y vocero del oneirodrama colectivo - reflexiona, informa, cuestiona, justifica e ilustra desde la inseminación de la obra hasta su alumbramiento y difícil ejecución. Encarna varias facetas y épocas críticas del creador y se reencarna directamente en sus dobles e indirectamente en sus otras criaturas de ficción, representantes de algún aspecto del novelar. Transportado al mundo novelístico por sus propios hijos literarios y a su mismo nivel, busca descubrir la base de la autonomía de éstos y del dominio que sobre él ejercen. Confiesa que tenía el "propósito dellevarlo a Martín hasta el suicidio"(250), pero no pudo hacerlo porque el personaje se le impuso y se salvó.

Cuando lo determinan fuerzas y eventos ajenos a sí mismo, el papel de Sabato es el de paciente pasivo, receptivo a las imágenes y situaciones que se le imponen. Pero es agente activo al articular sus percepciones (impresiones y sensaciones) y exponer los sentimientos e ideas del novelista, autocrítico, defensor de la verdad y en pos de la validación de su quehacer literario. Catania señala que, "para enjuiciarse como escritor, Sábato debe enjuiciar la literatura y encontrar respuestas para su justificación en este mundo. La desarma al tiempo que la defiende, como esos amantes desengañados una y otra vez, incapaces de sacudirse la pasión" (513-14). Como el amante apasionado, que en realidad está poseído por un afecto o complej ${ }^{38}$, el visionario, dominado por una energía psíquica ajena a él, se siente impelido hacia un ámbito desconocido, sin voluntad propia, desgarrado entre dos planos antagónicos de la realidad. El amante puede resolver el conflicto interno al diferenciar, reconocer y asimilar la proyección de la figura contrasexual opuesta a nivel individual. Pero la compulsión del visionario, multiplicada por la enormidad de la proyección colectiva, sólo se apacigua al darle expresión, pues no puede ser asimilada individualmente por su carácter transpersonal. Deallíla fuerza de los personajes autónomos y su poder magnético.

En Abaddón, Sabato representa algunas facetas del escritor Sábato, pero en función de personaje autónomo se conduce al mismo nivel ontológico de los otros seres de ficción. Sin las ataduras corporales explora un universo mítico en calidad de símbolo producido por energía psíquica acumulada, personal y transpersonal, consciente e inconsciente. Naturalmente, siendo imposible el ingreso físico en el mundo literario, Sabato se interna en la ficción como otro componente estructural psicológico del artista, parcialmente diferenciado durante el proceso de gestación de la novela. En el texto se relaciona con otros elementos diferenciados y algunas estructuras arquetípicas indiferenciadas o vagamente vislumbradas, para investigar los resortes misteriosos que motivan al artista.

38 Jung denominó complejos a las constelaciones alrededor de un núcleo o grupos de representaciones con fuerte carga emocional en el inconsciente. Como constituyente de la estructura psíquica inconsciente individual, el complejo es el medio autónomo por el cual se expresa la psique, tiene la capacidad de obsesionar o posesionarse de la voluntad de quien esté bajo su influencia sin que el afectado se dé cuenta cabal. 
En un primer movimiento introspectivo el artista desciende al yo, desde donde es impulsado al inconsciente transpersonal (colectivo), fuente de toda actividad genuinamente creadora. Alli lo confronta una extraña imaginería atávica -análoga a los sueños "grandes"-arquetípicos o chamanísticos y a visiones y percepciones místicas, apocalípticas, escatológicas, etc-que sobrepasa el posible conocimiento individual ${ }^{39}$. La inmersión en lo inconsciente para aprehender los misterios de la realidad total de la vida, la creación y los orígenes se inicia para Sabato como una intuición que elude la memoria,

como si lo tuviera 'en la punta de la lengua', y algo, una enigmática prohibición, una orden secreta, una potencia sagrada y represiva, se lo impidiera ver con claridad. Y lo sentía como una revelación inminente y a la vez imposible. Pero acaso ese secreto le fuera revelado a medida que avanzase, y quizá pudiese finalmente verlo a la luz terrible de un sol nocturno, cuando ese viaje terminara.(Abaddón 249).

La imagineria onirica comunica al consciente contenidos inconscientes relativamente fáciles de discriminar y asimilar individualmente. En cambio la imaginería mitopoética, de origen arquetípico, revela la estructura de la psique colectiva: los cimientos atávicos que van de loinstintivo (psicoide) a lo espiritual (arquetípico). Aunque el significado de contenidos inconscientes transpersonales de carácter compensatorio para la colectividad no se hace consciente al ego individual, el artista recupera una paz relativa al articular su percepción de la experiencia visionaria, aunque no la haya diferenciado ni asimilado personalmente.

En un cóctel al que asiste Sabato, "alguien comenzó un inventario de calamidades" mientras discutían un episodio relatadoen El túnel sobre el pianista obligado a comer una rata viva en los campos de concentración. Sigue una descripción gráfica de las quemaduras de napalm en gente todavía viva que produce "varias exclamaciones de horror" y disgusto, pero no cesa la fascinación con el desfile de torturas: "varios dijeron que ya todo se estaba poniendo muy feo, peronadie se movió, ... se esperaban nuevos ejemplos ..." (Abaddón 85). Sabato en su "persona" o máscara social "[i]mitóa Quique hablando sobre las necrologías, contó chistes ... Lo encontraban mejor que nunca ..." (93). Pero como siempre que se traiciona o enfrenta al horror de hechos inhumanos, se sintió arrastrado e "intuyó que aquello comenzaría, con invencible fuerza, pues nada podía

\footnotetext{
${ }^{39}$ Entre los estudios recientes sobre Shamanism se destacan el de Mircea Eliade y la compilación de ShirleyNicholson. También se menciona esta práctica en Rites and Symbols de Eliade (90-91). Según Eliade "initiation takes place during a mystical descent to the underworld" (Shamanism 51), parte del ritual incluye "the important element of an initiation .... dismemberment of the body ", con variaciones. El chaman por vocación empieza con sueños raros y alucinaciones desde la niñez [como Sábato]. Hay casos en que llegan a "tear of their eyes" (Shamanism 54) como le ocurre a Sabato que experimenta la extracción del ojo izquierdo frente a la Sra. de Falú sin que ella note el cambio - por ser simbólico (Abaddón 399).
} 
frenarlo una vez el proceso iniciado. No se trataba de algo horrendo, no aparecían monstruos", explica Sabato sobre este tipo de experiencia,

le producía ese terror que sólo se siente en ciertos sueños. Poco a poco fue dominándolo la sensación de que todos empezaban a ser extraños, algo así como lo que se siente cuando se ve una fiesta nocturna a través de una ventana ... Pero tampoco era eso exactamente: quizá como si además la gente quedara separada de él no por el vidrio de una ventana o por la simple distancia que se puede salvar caminando ... sino por una dimensión insalvable (93).

Frente a la frivolidad deshumanizante que lo rodea y a la trivialización del horror concretizado en el mundo moderno, la parte más sensible del artista reacciona proyectándose como observador descarnado, fuera de su caparazón o "persona" que sigue funcionando en el nivel social. El doble se desplaza "[c]omo un fantasma que entre personas vivientes puede verlos y oírlos, sin que ellos lo vean ni lo oigan. Aunque tampoco era eso". Así como son insensibles, inconscientes o ciegos al horror de los instrumentos inventados por el hombre para degradarse y destruirse mutuamente, los demás no advierten su cambio: “en ningún momento experimentaban la menor extrañeza, ignorando que el que hablaba con ellos no era S., sino una especie de sustituto, una suerte de payaso usurpador. Mientras el otro, el auténtico, se iba paulatina y pavorosamente aislando" (93-94). En su doble función de actor-espectador, el polo sensible de Sabato se aleja del círculo despreocupado e indiferente al sufrimiento ajeno, dejando la persona de Sabato con el grupo. El cuadro es más crudo aún en la yuxtaposición de vivencias de los aspectos más nobles de Sabato y otros espíritus puros, como la imagen de su madre en la memoria (97-99), la pureza de Marcelo y su abuelo $(81,88,94)$, Nacho y Agustina (57-62, 94), la actitud de rebeldía irreverente y amarga del primer mensaje de Jorge Ledesma (105-106), así como un poema de Sabato (94-96). Todo esto lo lleva a soñar con Alejandra en llamas que él siente como propias: "El agudo dolor y la ansiedad lo despertaron. Volvía el vaticinio ... la víctima y victimataria de su padre. Y Sabato volvía a preguntarse por qué la reaparición de Alejandra parecía recordarle su deber de escribir" (107).

\section{BRUNO, PERSONIFICACIÓN DEL EGO ARTÍSTICO EN ABADDON}

Aunque Sabato elucida acerca de su labor, no puede aclarar el significado de la producción nocturna. Pero Bruno, que encarna el pensamiento, da las claves y comentarios sobre muchos de los pasos de la creación literaria, por lo cual su función como ego discriminante capaz de soportar la tensión del conflicto creativo es indispensable para que el creador salga del subestrato nocturno (inconsciente transpersonal o colectivo). Esto no implica que Bruno sea una réplica de Sábato ni de Sabato, como se ha señalado. Desde Héroes, se considera 
a Bruno el alter ego de Sábato y portavoz de sus ideas ${ }^{40}$. Siebenmann observa sagazmente que en Abaddón hay una

voz narrativa autorial, la de él, Sábato, quien escribe cartas y trozos autobiográficos, quien cuenta, quien además se expresa a través de otros personajes heteronimos, pero idénticos evidentemente, aunque con diferentes facetas de su propia persona, efectuándose así la articulación de su ser complejo en varios estratos, la dramatización eficaz en el desempeño de varios papeles. Bruno ... reaparece como el bondadoso y razonable alter ego del autor (297).

Efectivamente, en Héroes Bruno personifica un alter ego de Sábato. Allí es una encarnación menos diferenciada y más humanizada que su sucesor: se enamora de la madre de Alejandra y un poco de la hija (Héroes 467), interactúa con los otros personajes de la novela y escribe únicamente cuando sufre (521). En Abaddón, se diferencian deliberada y conscientemente algunos aspectos psíquicos personales, por lo cual se pueden analizar más estrechamente a los heterónimos sabatianos. Bruno personifica el Logos, espíritu super consciente que salva al visionario de la disolución o vértigo. Funciona como filtro que reconoce, discierne y asimila los contenidos inconscientes individuales que se van haciendo conscientes en la personalidad del escritor, no así los contenidos transpersonales. La psicología analítica postula que todo contenido consciente previamente inconsciente (ignorado) ha sido necesariamente filtrado por el ego, sede de la razón, de la voluntad y centro de la psique individual. A medida que los contenidos inconscientes emergen, el ego se encarga de discriminar lo propio (individual) de lo no propio (colectivo), internalizando paulatinamente los materiales, a medida que se hacen conscientes, en una serie de etapas reconciliatorias en las que consiste el proceso centrifugo de integración ${ }^{41}$.

\footnotetext{
${ }^{40}$ Segre nota acertadamente que "[e]l Sábato que se mueve en el libro no goza de ninguna prerrogativa, ni como testigo ni como alter ego; tanto es asi que la historia se configura como proyecto de otro personaje, Bruno" (180), en tal caso Bruno es más que otro ego, es quien planea el proyecto, es el ego mismo.

"A nivel individual, se produce la reintegración de un ciclo en el proceso de "centroversión" (Neumann) o individuación (Jung) que lleva a la reconciliación paulatina de oposiciones, en diferentes etapas y niveles; proceso psicológico que marca la madurez emocional del individuo en general. Consiste en la gradual sucesión de etapas cíclicas que en cada nivel de desarrollo sigue un proceso de diferenciación de contenidos desconocidos (inconscientes), reconocimiento y subsecuente asimilación por el yo consciente (ego), asimilación que equivale a la reconciliación y reintegración de las oposiciones recientemente discernidas. Cada ciclo promueve una renovación o transformación en el desarrollo autocognoscitivo. Este proceso "laberíntico" según Jung, implica la discusión dialéctica entre "the conscious mind and the unconscious" (CW 12, par. 3). Tal discusion requiere la participacion consciente del ego como mediador entre estas contrapartes. El grado de autorrealización dependerá, naturalmente, de la capacidad de discernimiento y asimilación que tenga el ego-complejo que discrimina y asimila los contenidos previamente inconscientes.
} 
En su función del ego discriminado y discriminante del artista, Bruno es el asidero reintegrante durante los al tibajos del descenso de Sabato al abismo. Se caracteriza por su espíritu, sin cuerpo, con un sólo rasgo físico, sus ojos celestes tan claros como su mente (Abaddón 315). Es testigo de la actividad racional, emisor y receptor de las ideas, pensamientos, recuerdos y reflexiones de Sabato, pero no de la percepción del recorrido anímico: emociones intensas, afectos ni manifestaciones irracionales. Desaparece durante la experiencia subterránea de Sabato cuando cesa el diálogo entre ambos (376) puesto que a la razón no le es dado internarse en el submundo transpersonal ni al artista, como individuo particular, discriminar y menos asimilar sus contenidos. La tendencia del ego es controlar las fuerzas instintivas y la del individuo moderno es identificarse con su ego; por eso la función que cumple Bruno es de un valor extraordinario para entender el psicodrama íntimo del creador.

Generalmente, la concentración normal tiende a enfocarse en una actividad mientras otras actividades funcionan mecánica o inconscientemente; pero el artista de doble visión (lúcida y sensible) percibe sus desdoblamientos que son más marcados en épocas de desequilibrio social. En las primeras páginas de Abaddón, Bruno, en su función racional, atestigua un momento inicial crítico del descenso de Sabato en "lo que él llamaba un 'pozo" (11). La escisión del protagonista es semejante a la neurosis o disociación "disunion with oneself" (CW 8, par. 62). Sabato mira a Bruno sin verlo ni reconocerlo, pese a la estrecha relación que tienen, y cruza "la peligrosa esquina sin cuidarse para nada de los automóviles, sin esas miradas a los costados y esas vacilaciones que caracterizan a una persona despierta y consciente de los peligros"(Abaddón 11). El ego dscribe la conducta disyuntiva del artista que corresponde al abaissement du niveau mental, relajamiento del nivel consciente, esencial para el acceso espontáneo de la mentalidad moderna a la fenomenología psíquica transpersonal ${ }^{42}$. El desplazamiento del ego reduce la voluntad y energía propias que se transforman en energia vital y se constelan alrededor de la percepción del vidente, tarea que domina cualquier otro imperativo personal voluntario ${ }^{43}$. Esta situación dramatizada por un Sabato fuera de si, corresponde a la fase de incubación del

\footnotetext{
${ }^{42}$ Funciona espontáneamente como autoridad psíquica, igual que un complejo cuando una parte inconsciente de la psique se activiza atrayendo hacia síotras porciones del inconsciente y gana terreno al reforzarse con la compañía de éstas. Obtiene la energía necesaria del consciente (salvo cuando el sujeto se identifica con el complejo), ocurre entonces lo que Janet llama abaissement du niveau mental, apatía, desarrollo regresivo que sitúa al sujeto en una situación psíquica indiferenciada análoga a la del infante o a la del primitivo-en participation mystique con su medio. Prevalecen las funciones instintivas: la inocente apertura infantil y la inadaptacion sobre la moralidad. "The autonomous complex thus develops by using the energy that has been withdrawn from the conscious control of the personality" (CW 15, par. 123).

4s Se asemeja a la actividad patologica, sin serlo. Es una manifestación involuntaria náloga al estado inconsciente del primitivo denominado "pérdida del alma" o "loss of soul".
} 
proceso creativo visionario. Bruno, polaridad vigilante del creador, cavila sobre la enajenación del otro:

Empez6 a recordar algunos relatos que [S] le había hecho sobre maleficios, sobre un tal Schneider, sobre desdoblamientos. Un gran desasosiego comenz6 a apoderarse de su espiritu, como si en medio de un territorio desconocido cayera la noche y fuese necesario orientarse con la ayuda de pequeñas luces en lejanas chozas de gentes ignoradas, y por el resplandor de un incendio en remotos e inaccesibles lugares (11-12).

Bruno recuerda otros descensos y lejanas vislumbres de Sabato en el fondo del "pozo". Estas regiones, inaccesibles a la razón, limitan su propia visión y le impiden compartir la experiencia de Sabato en ese espacio psíquico. Sin embargo, las relampagueantes luces en la oscuridad que no orientaban a Castel, no extravían a Bruno, pese a su desasosiego y dudas; él es la fortaleza del espíritu que calma las emociones y equilibra los estados de ánimo inestables de la personalidad supersensitiva de Sabato. Bruno cede su supremacía, el control del ego, a los afectos de Sabato, sin juzgar, resistir ni intentar persuadirlo.

Numerosos pasajes ilustran la diferenciación de distintos niveles de conciencia distribuídos entre varios personajes y situaciones relacionados en el espacio atemporal de la memoria. Por ejemplo, mientras Sabato siente y vive una experiencia, Bruno interviene a menudo, entre paréntesis, con los recuerdos y reflexiones que la actitud de Sabato le hace evocar. Cuando Sabato ve a Nacho de niño, "representante de una parte decisiva" en su vida (cit. por Barrera 133), le "parecía un hijo de Van Gogh ... con los mismos ojos enigmáticos y verdosos" (Abaddón 25). Mientras Sabato asocia a Nacho, proyección de su pasado e ideales juveniles, con el pintor también visionario, interrumpe repentinamente un paréntesis de Bruno, con reflexiones análogas sobre las impresiones y añoranzas de la infancia de Sabato, juxtaponiendo pensamiento (Bruno) y sentimientos (Sabato) que tratan de duplicar la simul taneidad del funcionamiento psíquico:

(Paralizar el tiempo de la infancia, pensaba Bruno. Los veía amontonados en alguna esquina, en esas conversaciones herméticas que para los grandes no tienen ningún sentido. [i]A qué jugaban? ... Todo era distinto, pero acaso todo era igual en el fondo. Crecerian, tendrían ilusiones, se enamorarian, disputarian la existencia con ferocidad ... y todo volvería a empezar ... sentía necesidad de paralizar el curso del tiempo ... ) (25).

Cerrado el paréntesis de Bruno, Sabato siente un impulso "inexplicable [de] ... hablar con aquel chiquilín, sin saber que un día reaparecería" (26), para pedirle cuentas por sus acciones y actuaciones como personaje público, con la misma mirada que lo anonada, paralela a la dureza con la que Sabato se reprocha a sí mismo. Estimulado por la imagen infantil, Bruno verbaliza las constantes de la ensayística sabatiana sobre la creación de la novela total : la 
impotencia de la razón pura para trasformar la realidad; conmover; ofrecer esperanzas; proteger y preservar la pureza de la infancia y las ilusiones e idealismo de la adolescencia (25-26). Pero frente a tal angustia, Bruno, personificación de la razón, no es más que un “TESTIGO, TESTIGO IMPOTENTE”(14-18).

Las reflexiones de Bruno sobre el ensimismamiento de Sabato le traen a la mente la imagen de Martín pensando en Alejandra (ambos personajes de Héroes), lo que provoca en Bruno "la necesidad de escribir, aunque no le era posible comprender por qué ahora le nacia de ese encuentro con Sabato" (Abaddón 15), situación análoga al sueño de Sabato con Alejandra que también lo impulsa a escribir (107). Bruno se inquieta pues ya conoce esta fase durante la etapa de germinación de la creación visionaria que exige la introspección o descenso de Sabato en un desarrollo paulatino como el embrión que es. Como Sabato, Bruno cuestiona la habilidad de la memoria para revivir el pasado, la impotencia intelectual para conmover con el dolor distante y ajeno, o para eternizar a héroes y mártires. Se responde él mismo a sus dudas con el sentir y la fe de Sabato,

todo era muy complejo, porque si no habria que repudiar, como decía Sabato, la música y casi toda la poesía, ya que tampoco ayudaban a la revolución que esos jovenes ansiaban. Además, ningún personaje verdadero es un simulacro levantado con palabras: estaban construidos con sangre, con ilusiones y esperanzas y ansiedades verdaderas, y de una oscura manera parecían servir para que todos, en medio de esta vida confusa, pudiésemos encontrar un sentido a la existencia, o por lo menos su remota vislumbre. (15)

A través de Bruno, Sabato cuestiona el valor de la literatura (14-15), la defiende y critica, reafirmándose en la tarea de escribir. En su diálogo mental con lo que dice Sabato, Bruno entiende lo que a éste le pasa "en el fondo de su alma"; pero como ente racional, duda de la validez de la escritura, de su pretensión de mostrar la realidad total (racional e irracional) o de su capacidad de consolar y ayudar "de alguna manera a esa madre vietnamita que clama por su hijo quemado". Sabe que su escritura mesurada no lo conseguiría. "Pero ese milagro era posible y otros podían lograr lo que él no se sentía capaz de conseguir" (16), transmitir la esperanza implícita en la búsqueda absolutista del adolescente que el adulto deja atrás pero que el artista sensible todavía mantiene; facetairracional que una parte de Sabato comparte con sus personajes más puros, piensa Bruno y plantea el plan de la novela que leemos:

Una novela sobre esa búsqueda del absoluto, esa locura de adolescentes pero también de hombres que no quieren o no pueden dejar de serlo: seres que en medio del barro y el estiércol lanzan gritos de desesperación o mueren arrojando bombas en algún rincón del universo. Una historia sobre chicos como Marcelo y Nacho y sobre un artista que en recónditos reductos de su espíritu, siente agitarse a esas criaturas (en parte vislumbradas fuera de $\mathbf{s}$ mismo, en parte agitadas en lo más profundo de su corazon) que demandan eternidad y absoluto .... (17). 
En un ir y venir entre el pensamiento de Bruno y los sentimientos de Sabato que "siente agitarse a esas criaturas ... vislumbradas fuera de si mismo", Bruno, carente del calor e intensidad emocional e irracional del ente corpóreo, duda, "con aquel exceso de honradez que lo hacía vacilante y en definitiva ineficaz ... incapaz de esos actos absolutos de la pasión y el herórsmo" (15). La razón y la voluntad sin la participación de los sentidos, emociones e intuiciones es incapaz de crear la novela total, que postula Sábato, pero su participación como conciencia vigilante es imprescindible para la escritura de la obra.

Como señalan Barrera, Montenegro, Petrea, et al., Bruno es el hilo conductor que abre y cierra la novela, pero, a diferencia de los participantes activos, "Bruno is protrayed in a passive role"; según Montenegro, "the expression Bruno thought, repeated by the narrator gives the key to his personality. Bruno only functions on a mental level" (53). En efecto, Bruno no reacciona irracionalmente como un ser humano complejo sino hasta el final de la narración cuando adquiere cuerpo y se humaniza. Hasta entonces sólo tiene el sentido de la vista y el del ofdo, no muestra emoción alguna -aunque tampoco puede comparárselo con el racionalismo unilateral que el Dr. Carlitos Arrambirre tipifica (Abaddón 136-45). Comprensivo, compasivo y consciente de las más nobles aspiraciones humanas, Bruno se da cuenta de la imposibilidad de trascender por la via racional únicamente.

Al responder las preguntas de un grupo de jóvenes, Sabato - que encarna además del intelecto los aspectos más humanos del artista, sentimientos, emociones intensas, sensaciones y la percepción intuitiva del visionarioreacciona emocionalmente, mientras Bruno apenas "se sentía incómodo" (169) ante la discusión entre ellos. Los jóvenes cuestionan a un Sabato abrumado que, si bien arguye lúcidamente, reacciona al dogmatismo arrogante de algunos tratando de marcharse. Mientras tanto, Bruno, que cavilaba sobre la heterogeneidad del grupo aunque también "quería irse", interviene en silencio para calmar a Sábato "tomándolo suavemente de un brazo" (182-85), formulando al mismo tiempo los pensamientos de Sabato y el efecto de estas criaturas en éste.

Bruno acompaña a Sabato en sus caminatas por los parques y lo escucha en los cafés, elaborando y meditando sobre lo que dice, piensa y hace. Mientras Sabato distraído o bajo un impulso camina "sin rumbo fijo" (387), siempre sucede algo importante (cf. 54, 62, 88, 255, 261, 287, 411). A continuación, el proceso dialéctico de Bruno evalúa una frase común y examina la dicotomía de la voluntad consciente y el destino inconsciente, mientras Sabato siente la experiencia sensual del caminar

sin rumbo fijo. Expresión que en ese momento surgió en su mente, lo que demostraba, en opinión de Bruno, que hasta los escritores se dejan llevar por las expresiones corrientes, tan superficiales como falaces. Porque siemprecaminamos con un rumbo fijo y, a veces, lo que resulta todavía más asombroso, demostrando a la larga tener más razón que nuestra voluntad consciente 'S'. sentía bajo sus pies las blandas hojas (387). 
Bruno medita sobre la sabiduría del inconsciente como una "voluntad desconocida" pero no actúa. Solamente tras la muerte de su padre, un Bruno más humano que el crítico de "expresiones corrientes", igual que Sabato, Marcelo y Nacho anteriormente, "caminó sin rumbo" (467) y "ambuló hasta la madrugada" (469), irracionalmente y sufriendo como ellos.

Mediante la yuxtaposición de las figuras y alternancia de voces narrativas, reflexiones, viajes rememorativos y acciones espontáneas, Bruno narra los pensamientos de Sabato y comenta sobre los sentimientos de éste en relación a las memorias de la infancia del angustiado Nacho. Este, asqueado de la vida, de la perversidad y de las noticias (como Castel y Sabato), mirando a las fieras frente a una jaula del zoológicorevive sus conversaciones infantiles con Carlucho, ejemplo de sencillez y justicia. Sabato atisba a Nacho, "fascinado por su presencia y por su actitud estática y contemplativa" (388). Simultáneamente Bruno, nostálgico, desde la mente de Sabato sigue el desfile reflexivo y los sentimientos de éste, quien a su vez penetra en la memoria de Nacho que evoca la candidez de Carlucho, capaz de entender y comunicarse con las fieras. El ir y venir en el tiempo y el espacio dramatizan el funcionamiento de diversos componentes psicológicos diferenciados en el texto. Sabato y Nacho comparten pensamientos, el estado de ánimo sobre las fieras y hasta la manera de caminar:

PoRque, qué CLASE DE TERNURA', qué palabras sabias o amistosas -pensó Bruno que pensaba Sabato-, [i]qué caricias podían alcanzar el corazón escondido y solitario de aquel ser, lejos de su patria y de su selva, brutalmente separado de su raza, de su cielo, de sus frescas lagunas? No era difícil que cavilando en esas penurias Nacho bajara finalmente sus brazos $y$, encorvado y pensativo ... pateando distraídamente alguna piedrita, caminara luego ... [i] Hacia dónde? [i]Hacia que soledades todavía? (398).

Consciente de la nostalgia regresiva de Sabato/Nacho, paralela a la atribuída por ellos a las fieras desarraigadas de su lugar de origen, Bruno cierra el párrafo anterior identificándose a sí mismo con la mente y a Sabato con el cuerpo en camino hacia el ritual iniciático de éste: "Pero como el corazón del hombre es insondable - se decía Bruno - con ese pensamiento en su cabeza, el cuerpo de S. se dirigió hacia la calle Cramer, donde se encontraría con Nora" (399). Aunque Bruno anhela lo absoluto no se lanza en su búsqueda como Sabato (14$18,168,185)$, pero se desplaza sin revelarse ni intervenir, dando paso a las fuerzas inconscientes que invaden a Sabato y retorna cuando la razón se hace necesaria para recobrar el equilibirio.

A lo largo de la narración, Bruno supervisa las actividades físicas y psicológicas de Sabato. Funciona como confesor, cuando Sabato le confía sus dudas y temores (21-28, 64-76, 267-310,314-330); como oyente activo y receptivo, al escucharlo sin interrumpir ni aconsejar; como asesor pasivo, que apenas contesta con monosílabos y sólo para reasegurar a un Sabato paranoico plagado 
de amenazas sombrías (Schneider, Hedwig, los sueños de M., R, el Dr. Schnitzler314-22). Además comparte las ideas de Sabato sobre el arte y la vida. Presenta el programa y teoría de la novela total (14-17) y reconoce, a veces mejor que Sabato (188), a personajes de las novelas anteriores de Sábato - e.g., a Castel de El túnel (Abaddón 167-68), a Alejandra y Martín de Héroes (Abaddón 204209); ya había ejercido el mismo papel de "mute analyst, the omnipresent confessor" (Foster 86) con Martín. También informa sobre el estado externo de Sabato, contempla y comprende su actitud, su conducta, sus reacciones visibles (Abaddón 53-54, 62-63, 170-77), las describe $(11,170)$ y entiende la situación de Sabato. Pero no toma parte en las experiencias de naturaleza transpersonal (54$63,373-450$ ); registra únicamente las señales externas del descenso: "Bruno lo encontró raro y le preguntó por su salud" (314). En otra ocasión, "encontró a S. como ausente como quien está fascinado por algo que lo aísla de la realidad, pues apenas pareció verlo" (373), "intuyó que una misteriosa sustancia había caído en el fondo de las aguas profundas de su amigo" (375). En la primera página lo encuentra en su pozo, ya autoescindido (11) y casi al final lo sigue cuando se encamina a su inmersión simbólica (376). Bruno desaparece durante la experiencia ritual de Sabato con Soledad y R. en el submundo; durante sus desdoblamientos en París; cuando confronta su propio cuerpo vacío hasta que se une a éste $\mathrm{y}$, en su monstruosa metamorfosis. Antes de su descenso, Sabato cavila que"jamás relató a nadie los hechos vinculados con Soledad, si exceptuaba a Bruno", pero sólo después de discriminar su posible sentido "casi cuarenta años más tarde, cuando por primera vez le contó a Bruno, como si en aquel entonces sólo hubiese tomado una fotografía y recién después de tanto tiempo fuera capaz de interpretarla" (413). Sabato se refiere a una experiencia límite en 1927 que se hace parcialmente consciente al ego (Bruno) en 1967, pero "nada le dijo [a Bruno] del monstruoso rito" (413), lo cual subraya la inhabilidad de la razón para asimilar este tipo de experiencia.

Llamado por su familia a Capitán Olmos, Bruno se encarna visiblemente. El espíritu vigilante que únicamente dialogaba con Sabato o con evocaciones reanimadas de Héroes (Martín, Alejandra, Castel), pero invisible a los otros actores de Abaddón, retrocede en el tiempo y espacio para retornar "después de 25 años" (450) a su pueblo natal, en 1953 (470). Por primera vez en'la novela habla con alguien que no sea Sabato; con la gente del pueblo, con su padre agonizante y con sus hermanos (454-64) ${ }^{4}$. Regresa nuevamente al pueblo veinte años después, en 1973, tras las experiencias visionarias de Sabato; y esta vez es

\footnotetext{
${ }^{44}$ Por eso dice Ortega que "El itinerario final de Bruno supone un enfrentamiento contra los fantasmas del pasado. El retorno a la casa de su agonizante padre tiene, como el viaje de Martín a la Patagonia, un importante valor catártico... Bruno, que también persiguió, como Martín, un quimérico absoluto, toma conciencia al final del relato de que 'su existencia habia sido un correr detrás de fantasmas, de cosas irreales' [A 522]" (147). Salvo que la muerte "se trata del padre de Ernesto Sábato" de acuerdo a Barrera Lopez entre otros críticos enterados "por informaciones textuales y extratextuales" (72).
} 
Bruno quien tiene una visión: la tumba de Sabato en Olmos, en lugar de "su pueblo verdadero Rojas" (472), pueblo natal de Sábato y del personaje Sabato. Pero es en Capitán Olmos, espacio literario atemporal y cuna de Bruno, donde se imagina haber visto la tumba de Sabato sin fecha, con la única inscripción que éste quiere: “PAZ”, indicio de que el artista ha encontrado la paz en la articulación del texto. Bruno responde a lo

[i]qué significaba esa visión? Un deseo, una premonición, un amistoso recuerdo hacia su amigo? Pero cómo podra considerarse como amistoso imaginarlo muerto y enterrado? En cualquier caso ... era paz lo que seguramente ansiaba y necesitaba, lo que necesita todo creador, alguien que ha nacido con la maldición de no resignarse a esta realidad que le ha tocado vivir ... no hay felicidad absoluta, pensaba. Apenas se nos da en fugaces y frágiles momentos, y el arte es una manera de eternizar (de querer eternizar) esos instantes de amor o de extasis ... (472 mi énfasis).

Se ha interpretado esta visión imaginada de Bruno como una visión concreta de la tumba de Sabato, que también sería simbólica, pero al ser imaginaria ilustra la relación íntima entre ambos y una transformación o renacimiento. Para Bruno, es una etapa involutiva irracional -ingreso y salida del submundo- después de la cual, recuperada el alma por el ego se invierten los papeles. Ahora, es Bruno-poeta quien se dirige a su amigo interior: "cuánto te comprendo para querer verte enterrado, descansando en esta pampa que tanto añoraste, y para soñarte sobre tu lápida una pequeña palabra que al fin te preservase de tanto dolor y soledad!" (473). Esta es una situación arquetípica de carácter iniciático: retorno ritual a la madre tierra (tumba-inconsciencia) presenciado y diferenciado en un rito simbólico por el ego previamente discriminado. La reconciliación de estas oposiciones supone la trascendencia a otro nivel de conciencia. En este nuevo estado, Bruno"salió del cementerio con un sentimiento que nada tenía de trágico" después de imaginar la tumba, señal de renovación, puesto que la muerte implica transformación y renacimiento. $\mathrm{Su}$ entorno le produce "esa sensación de melancólico reposo que se siente de niño cuando se pone la cabeza en el regazo de la madre, cerrando todavía los ojos llenos de lágrimas después de haber sufrido una pesadilla" (472). Este nuevo estado de paz, seguridad y confianza, muy diferente al de sus dudas einseguridad anteriores es la consecuencia de una autorrealización, equivalente a un ciclo superado.

FUNCION ESTRUCTURAL DE LOS PERSONAJES Y ANIMACIONES SIMBOLICOS EN LA NARRACION

Como los sueños que reiteran imágenes simbólicas con el mismo motivo central, Sábato vivifica sus obsesiones a través de sus personajes. Para Calabrese: "Quedan en pie varias cuestiones a resolver, así el interrogante sobre 
la reaparición de personajes de otras ficciones, los cuales transitan la misma dimensión que el propio NP [narrador-personaje]; finalmente el por qué de su misma existencia novelística, ya que no cumplen ninguna función en el nivel de las acciones" (186). En efecto, algunas figuras no funcionan "en el nivel de las acciones", sino que personifican aspectos de la personalidad del artista, mientras otras representan o animan emanaciones de lo inconsciente transpersonal, nivel donde la acción responde sólo a un funcionamiento intangible, evidente tan solo por sus manifestaciones fenomenológicas psíquicas. Estas figuras no adquieren cuerpo y se interrelacionan únicamente con Sabato en un espacio íntimo, onírico o mitopoético. Sabato funciona como el eje estructural narrativo y centro de referencia con quien se pueden comparar y contrastar todos los personajes, experiencias y eventos en la narración; él es quien mantiene contacto con las polaridades divergentes. Sólo él trata con figuras o animaciones simbólicos como R., Soledad, Jorge Ledesma y un grupo de entes que lo asedian. Bruno solamente conoce a algunos de éstos en sus diálogos con Sabato, aunque ve a personajes intertextuales como Castel de El túnel y recuerda a, o sueña con Alejandra y Bruno de Héroes.

Los personajes de Abaddón que representan tendencias colectivas sombrías comoSchneider, Schnitzer, Citronenbaum, Costa, identificables con tipos sociales reconocibles peroexternos al individuo, norevelan sus móbiles ni se substancializa su función. La misma atmósfera sombría e incomprensible que los une, los aparta de la experiencia individual cotidiana. El distanciamiento del lector se incrementa frente a la animación de entes enigmáticos como R., sombra que lo llama "su gemelo astral" y con quien Sabato sólo se comunica "en la soledad y en las tinieblas" (269); figuras teriomórficas como Nora, Soledad (ánima), la ratamurciélago alada en que Sabato se convierte (sombra colectiva), animación de actividades y situaciones rituales (descenso de Sabato a los subterráneos bonaerenses mientras su mente permanece en un jardín abandonado y su cuerpo lo espera en casa), además de otros desplazamientos de un Sabato desencarnado (desdoblamiento en el cóctel, experiencia con la ciega en París, extracción simbólica del ojo izquierdo en público, ascenso entre la fauna subterránea), posibles sólo en el ámbito mítico (psíquico). En estos desdoblamientos, Sabato revive el rito primitivo de participation mystique ${ }^{45}$, con

${ }^{45}$ (Término de Lucien Lévy-Bruhl, etnólogo francés). Jung explica que: "[r]esumergirse en el estado primordial de la participation mystique es el secreto de la creación de arte y de su efecto, pues sobre este grado del vivenciar no vivencia ya el individuo sino el pueblo, y no se trata allí ya del bienestar y dolor del individuo sino de la vida del pueblo. Así, la gran obra de arte es objetiva e impersonal, y sin embargo nos toca en lo más profundo" (Simbolos 14). El estado de identificacion del hombre primitivo con su grupo se recrea bajo circunstancias especiales mediante motivos mitológicos. El arquetipo de participation mystique recrea innumerables experiencias filogéneticas originales. Según Neumann, en la primera etapa de desarrollo de la humanidad se puede ver: "the group as an integral psychic field, in which the reality of the individual is embedded, so that he is organ and instrument of the collective" (Art 88). 
la naturaleza, proceso vital disyuntivo e imperioso que comprende desde la inseminación hasta el nacimiento de la novela entretejida con el material problemático de la vida humana diaria, en una compleja visión recreada desde una diversidad de ángulos conceptuales y anímicos.

Laluchainterna que Castel sostenía consigo mismoen El túnel se dramatiza en una compleja interacción en Abaddón. Los personajes surgidos de la profundidad y animados por la intensidad vital de la experiencia del explorador subterráneo dan al arte esa oportunidad de redimir la inercia racional que Bruno ejemplifica, su abúlica y "crónica impotencia frente a la inmensidad" de la naturaleza insensible que condiciona un universo.de "[c] atástrofesy tragedias, amores y desencuentros, esperanzas y muertes, [que] le daban la apariencia de lo inconmensurable. [¿]Sobre qué debería escribir? [¿]Cuáles de esos infinitos acontecimientos eran esenciales?" (15).

Abaddón es la psicobiografía del creador Sábato en cuanto relaciona hechos y actitudes compulsivas que determinaron su vía artística y es también una biografía espiritual en cuanto expresa las aspiraciones y anhelos de superación sobre la vida materialista. Pero sobre todo, revela un ahondamiento en el alma o psique inconsciente de su pueblo y de su momento histórico, con el riesgo implícito de quedar atrapado en el vértigo de un abismo sin fondo, que sin embargo el artista exorciza al dar expresión a sus visiones. Al hacerlo, cae en otros riesgos menos peligrosos, pero muy molestos para el visionario por su extrema sensibilidad; riesgos comoel ridículo por la incredulidad e incomprensión de la mentalidad media ortodoxa, la maledicencia y burla por un ladoy, por otro, la exposición pública de la propia psicobiografía que supone despojarse de coberturas conscientes y máscaras sociales; disectarse en público. Además, al desencubrir las imágenes del ámbito instintivo más secreto, vergonzoso y detestado por el canon o consciente colectivo -aunque es compartido por la humanidad - el creador se asegura una vasta oposición y la crítica voraz de los más cercanos adherentes al canon social vigente.

La apariencia caótica e incomprensible de algunas situaciones y personajes y la pluralidad de perspectivas a diversos niveles de conciencia (intelectual, sensorial, perceptivo, intuitivo y afectivo) se va aclarando al seguir los patrones arquetípicos que descubren la unidad estructural profunda de la narración que da a la ficción sabatiana una coherencia vivencial. A primera vista la novela impresiona como un rompecabezas que hace falta reconstruir; los apartados colocados sin orden alguno duplican los saltos prospectivos y retrospectivos, involutivos y evolutivos de la psique. La fragmentación de la forma busca reproducir la ruptura del tiempoy del espacio lineal (necesariamente sucesivos en la narración) para dar el efecto de la simultaneidad recreable sólo en el espacio onírico o mitopoético de la psique humana aunque no se logre captar su intelección ${ }^{46}$.

${ }^{46}$ A este respecto dice Jung: "In myths and fairytales, as in dreams, the psyche tells its own story, and the interplay of the archetypes is revealed in its natural setting as 'formation, transformation / the Eternal Mind's eternal recreation" (CW 9, I, par. 400). 
Aunque la mentalidad exclusivamente racionalista no acepta la fenomenología de lo inconsciente ni las dotes visionarias del escritor Ernesto Sábato, una gran parte de la crítica (Callan, Chiesi, Gimelfarb, Martínez, Maturo) la menciona y reconoce. Para Ortega “Abaddón representa uno de los más angustiosos documentos novelísticos del siglo XX realizado por un lúcido y visionario testigo de los terrores de nuestro tiempo" (151). Sin intentar definir o describir específicamente el fenómeno de la videncia y clarividencia del artista visionario, la personalidad de Sábato, sus confesiones y declaraciones, sumadas a su ficción, respaldan y valorizan los postulados de Jung sobre la experiencia visionaria, aclarando en gran parte un fenómeno extremadamente complejo para la mentalidad racional. Establecidos los límites de los personajes verosímiles, se hace más perceptible la producción originada por la polaridad visionaria aunque continúe enigmática.

Como toda actividad humana derivada de la psique, el arte puede estudiarse desde una perspectiva psíquica sin por eso devaluar otros acercamientos, recuperando más bien una dimensión cognoscitiva profunda personal y transpersonal. Con una novela tan vasta como Abaddón, como es el caso de toda gran obra de arte, ningún estudio será definitivo. Además de ideas y reflexiones del pensador se acumulan las obsesiones, afectos, sentimientos y el escrutinio masivo y ambivalente de aspectos inconscientes indescriptibles e incongruentes aún para el propio Sábato. Pero al seguir el recorrido lúcido del artista se aclara una buena parte del proceso creativo psicológico que concluye en una reintegración a nivel personal en la figura de Bruno. Por contraste se destacan los espacios, imágenes y aspectos indiferenciados que no se integran, mantienen su misterio y quedan en suspenso, amorfos, fragmentados, indiferentes y amenazantes. 


\section{FUENTES CONSULTADAS}

Balkenende, Lidia. Aproximaciones a la novelística de Sábato. Buenos Aires: Agencia Periodística C.I.D., 1983.

Barrera López, Trinidad. La estructura de "Abaddón, el Exterminador". Escuela de Estudios Hispano-Americanos de Sevilla, 1982.

Calabrese, Elisa. "Personajes de Abaddón: máscara e identidad". VásquezBigi (183-91).

Catania, Carlos. "El universo de Abaddón el exterminador". Cuadernos Hispanoamericanos 391-393 (1983): 498-516.

Eliade, Mircea. Rites and Symbols of Initiation: The Mysteries of Birth and Rebirth. Trad. Willard R. Trask. New York: Harper, 1975.

. Shamaniism: Archaic Techniques of Ecstasy. 1951. Trad. Willard R. Trask. Princeton UP, 1974.

Foster, David William. "Ernesto Sabato and the Anatomy of a National Unconscious". Currents in the Contemporary Argentine Novel. U of Missouri $P, 1975$ : 70-97.

Jung, Carl G. The Collected Works, comp. Herbert Reed et al. Trad. R. F. C. Hull. Bollingen Series XX. Princeton UP, 1978.

- Memories, Dreams, Reflections. New York: Pantheon, 1962.

- Símbolos de transformación. Edición revisada y aumentada de Transformaciones y símbolos de la libido, comp. Enrique Butelman. Barcelona: Paidós, 1982.

Montenegro, Nivia. "Structural and Thematic Elements in Abaddón: el exterminador (Abaddón the Exterminator)". Latin American Literary Review 12 (1978): 39-56.

Neumann, Erich. Art and the Creative Unconscious. Trad. Ralph Manheim. Princeton UP, 1971.

. The Origins and History of Consciousness. 1954. Trad. R. F. C. Hull. Princeton UP, 1973.

Ortega, José. "Las tres obsesiones de Sábato". Cuadernos Hispanoamericanos 391-393 (1983): 125-51.

Progoff, Ira. The Death and Rebirth of Psychology: An Integrative Evaluation of Freud, Adler, Jung and Rank and the Impact of Their Insights on Modern Man. New York: McGraw, 1973.

Sábato, Ernesto. Abaddón el exterminador. 1974. Barcelona: Seix Barral, 1a. ed. Fomentor 1982.

. El escritory sus fantasmas. 1963. 4a. ed.. Buenos Aires: Aguilar, 1971.

Segre, Cesare. "Cuando llega el exterminador (Término de la famosa trilogía de Ernesto Sábato)". Vásquez-Bigi, A.M. (179-82).

Siebenmann, Gustav. "Ernesto Sábato y su postuladode una novela metafísica". Revista Iberoamericana 118-119 (1982): 289-302.

Vásquez-Bigi, A.M., ed. Epica dadora de eternidad: Sábato en la crítica americana y europea. Buenos Aires: Sudamericana/Planeta, 1985. 
Wainerman, Luis. Sábato y el misterio de los ciegos. Buenos Aires: Castañeda, 1978. 
